\title{
61. LOWER CRETACEOUS PELAGIC SEDIMENTS OF DEEP SEA DRILLING PROJECT SITE 603, WESTERN NORTH ATLANTIC: A SYNTHESIS1
}

\author{
James G. Ogg, Department of Earth and Atmospheric Science, Purdue University \\ Janet Haggerty, Department of Geosciences, University of Tulsa \\ Massimo Sarti, Instituto di Geologico, Università di Ferrara \\ and \\ Ulrich von Rad, Bundesanstalt für Geowissenschaften und Rohstoffe ${ }^{2}$
}

\begin{abstract}
Pelagic sedimentation during the Early Cretaceous at Site 603 produced alternations of laminated marly limestone and bioturbated limestone-a facies typical of the "Blake-Bahama Formation" of the western Atlantic. This limestone is a nannofossil micrite, rich in calcified radiolarians, with variable amounts of organic matter, pyritized radiolarian tests, fish debris, and micaceous silt. The laminated marly limestone layers are enriched in organic matter when compared with the intervals of bioturbated limestone. The organic carbon is predominantly terrestrial plant debris; where the organic-carbon content is in excess of $1 \%$, there is also a significant marine-derived component. Laminations can result either from bands of alternately enriched and depleted opaque material and clay, or from bands of elongate lenses (microflasers) of micrite, which could be plastically deformed pellets or diagenetic features. The alternating intervals of laminated and bioturbated structures may have resulted from combined changes in surface productivity, in the influx of terrigenous organic matter, and in the intensity of bottom circulation, which led to episodic oxygen depletion in the bottom water and sediments.

Variations in the relative proportions of laminated clay-rich and bioturbated lime-rich limestone and in the development of cycles between these structures make it possible to subdivide the Lower Cretaceous pelagic facies into several subunits which appear to be regional in extent. Bioturbated limestone is dominant in the Berriasian, laminated marly limestone in the Valanginian and Barremian-lower Aptian, and well-developed alternations between these end members in the Hauterivian. The Hauterivian to lower Aptian sediments contain abundant terrigenous clastic turbidites associated with a submarine fan complex. These changes in the general characteristics of the pelagic sediment component of the Blake-Bahama Formation at Site 603 are synchronous with those in the Blake-Bahama Basin (Sites 534 and 391 ) to the south. Carbonate sedimentation ended in the early Aptian, probably because of a regional shoaling of the carbonate compensation depth.
\end{abstract}

\section{INTRODUCTION}

Deep-sea sedimentation during the Early Cretaceous was dominated by radiolarian-rich nannofossil ooze. Although there is considerable local and temporal variability in the clay and organic-matter content and in the clastic influx from the continental shelves, pelagic sediments in the North Atlantic basins, in the Tethys seaway, and in the Gulf of Mexico basin are in general very similar. In the western basin of the North Atlantic, this facies has been drilled at several Deep Sea Drilling Project sites (Sites 4, 5, 99, 105, 387, 391, 534, and 603; Fig. 1) and was formally designated as the "Blake-Bahama Formation" after its thickest development in the Blake-Bahama Basin (Jansa et al., 1979) ${ }^{3}$. This facies, or formation, extends from the late Tithonian (uppermost Jurassic) to the early Aptian (uppermost Lower Cretaceous), and is generally overlain by black organic-carbon-rich claystone ("Hatteras Formation").

\footnotetext{
${ }^{1}$ van Hinte, J. E., Wise, S. W., Jr., et al., Init. Repts. DSDP, 93: Washington (U.S. Govt, Printing Office).

2 Addresses: (Ogg) Dept. of Earth and Atmospheric Science, Purdue University, West Lafayette, IN 47907; (Haggerty) Dept. of Geosciences, University of Tulsa, Tulsa, OK 74104; (Sarti) Instituto di Geologico, Universitả di Ferrara, Corso Ercole d'Este 32, 1-44100, Ferrara, Italy; (von Rad) Bundesanstalt für Geowissenschaften und Rohstoffe, Postfach 510153, D. 3000 , Hannover, Federal Republic of Germany.

3 The earlier informal name "Tithonian-Neocomian White and Grey Limestones" (Lancelot et al., 1972) was more descriptive.
}

Drilling at Site $603\left(35.29^{\circ} \mathrm{N}, 290.0^{\circ} \mathrm{E}\right.$; Fig. 1) penetrated approximately $360 \mathrm{~m}$ of Lower Cretaceous carbonates and clastics. ${ }^{4}$ At Site 603 , the regional BlakeBahama Formation facies, with quasicyclic alternations of bioturbated limestone and laminated marly limestone, is interbedded in the Hauterivian through lowermost Aptian by terrigenous clastic turbidites from a major submarine fan complex.

This chapter will summarize various studies of the pelagic carbonates; the turbidites of the submarine fan complex are described in detail by Sarti and von Rad (this volume). These studies and other data sources include: (1) the core and thin-section descriptions, and the preliminary shipboard sedimentological report (a condensed version of which appears in the Site 603 chapter, this volume); (2) supplemental thin sections (by the authors), X-ray diffraction analyses (by H. Rosele), and visual observations (made at the Lamont-Doherty core repository); (3) geochemical, stable-isotope, and scanning electron microscope (SEM) studies (by Dean and Arthur, by Baltuck, and by Haggerty, all this volume) and a review of organic geochemical studies (Meyers,

\footnotetext{
4 Four holes attempted during Legs 93 and 95-603B, D, E and F-recovered Lower Cretaceous strata; only 603B had continuous coring, and all holes terminated in the uppermost Berriasian or lower Valanginian because of a variety of technical problems, including the total loss of a drill string during Leg 93 .
} 


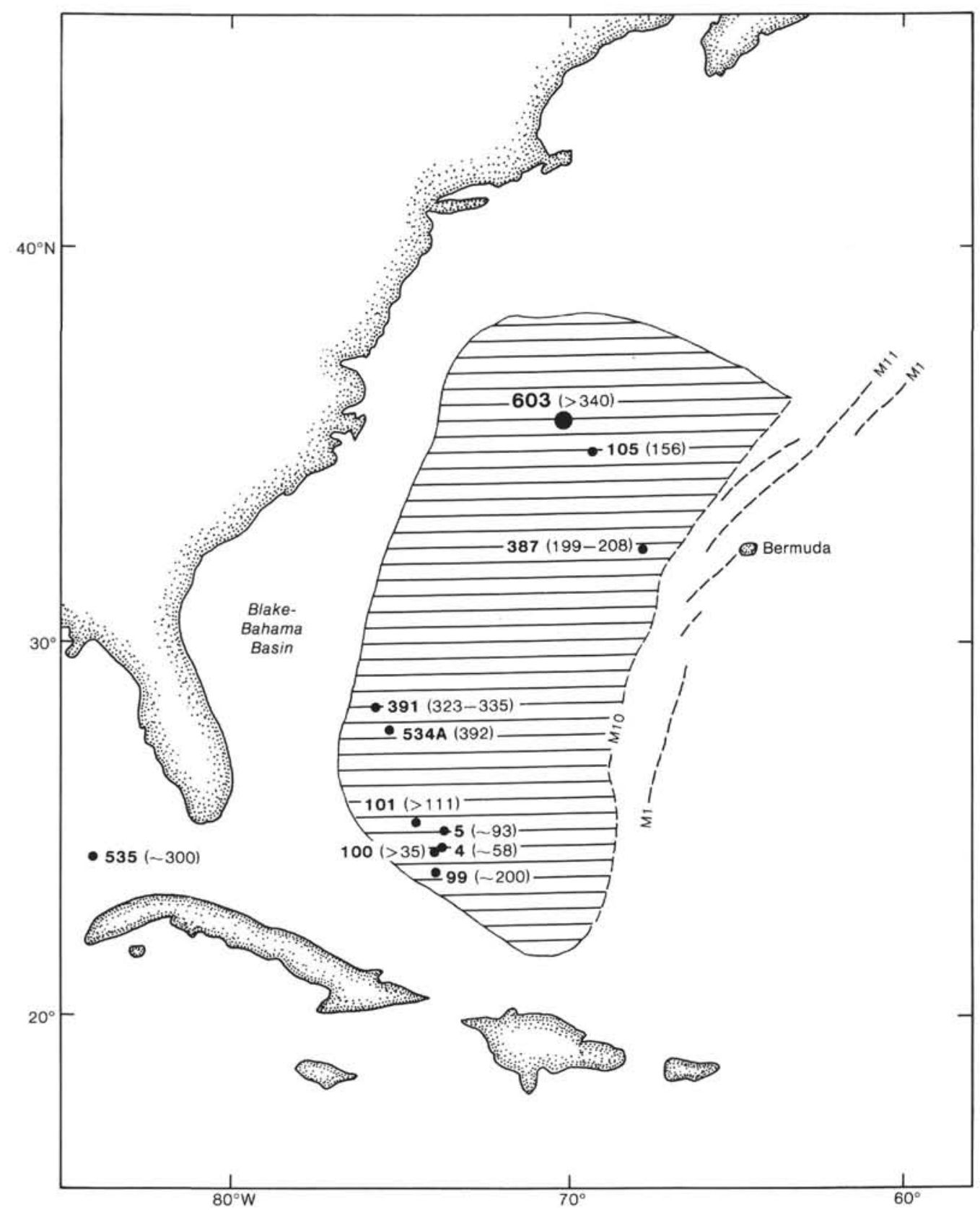

Figure 1. Location of DSDP Site 603 and other DSDP sites recovering Lower Cretaceous pelagic sediments in the western Central Atlantic (North American Basin). Total thickness (in m) of Lower Cretaceous (Berriasian-lower Aptian) sediments at each site is given in parentheses after the site number. The regional extent of the seismic horizon $\beta$ is indicated by the horizontal lines (diagram from Jansa et al., 1979). Horizon $\beta$, often associated with the Barremian/Aptian boundary in the sediments (or the top of the Blake-Bahama Formation), can be resolved seaward to magnetic Anomaly M11 (Valanginian/Hauterivian boundary in age); however, the Lower Cretaceous strata should be present on oceanic crust as young as magnetic Anomaly MO (early Aptian age). Modified after Robertson and Bliefnick, 1983.

this volume); and (4) related studies on the paleontology, magnetostratigraphy, and chemistry by the shipboard scientific party and shore-based investigators. Following an overview of the lithology, the sedimentary structures, textures, microfacies, and geochemistry will be summarized. The most striking aspect of the Blake-Bahama Formation is the cyclic alternation of laminated and bioturbated structures; these will be emphasized in the summaries and a possible model of their origin will be brief- ly presented. In the concluding section, the main facies within the Lower Cretaceous pelagic limestone at this site will be summarized. Syntheses of the sedimentology of previous DSDP sites coring the Blake-Bahama Formation and similar Lower Cretaceous sediments include those of Sites 99 and 105 (Lancelot et al., 1972; Bernoulli, 1972), Site 387 (Tucholke and Vogt, 1979), Site 391 (Freeman and Enos, 1978), Site 534 (Robertson and Bliefnick, 1983), Sites 535 and 540 (Cotillon and Rio, 
1984); regional comparisons are given by Jansa et al. (1978, 1979), by Tucholke and Mountain (1979), and by Müller et al. (1983, 1984). As would be expected, several of the sedimentological and geochemical features observed at Site 603 are general characteristics of the Blake-Bahama Formation.

\section{LITHOLOGIC OVERVIEW}

A total of $361.5 \mathrm{~m}$ of Lower Cretaceous (uppermost Berriasian through lower Aptian) limestone interfingering with siliciclastic turbidites was penetrated at Hole 603B and designated as Lithologic Unit V (Cores 603B44 through $-82 ; 1214.7-1576.2$ m sub-bottom $^{5}$ ) (Fig. 2). This unit is overlain by greenish and redish claystone, containing black organic-carbon-rich claystone (lithologic Subunit IVD; Aptian age). The contact (603B-44-1, $32 \mathrm{~cm}$ ) appears to be sharp, although it is possible that as much as $4 \mathrm{~m}$ of the transition zone were not recovered. Lithologic Unit V is equated with the regional BlakeBahama Formation in this chapter; however, the definition of the upper contact may not coincide with the formal definition of the top of the Blake-Bahama Formation of Jansa et al. (1979), as will be discussed later.

Four main lithologies occur in varying relative proportions in the Lower Cretaceous of Site 603: (1) gray, laminated marly limestone ${ }^{6}$, (2) white bioturbated limestone, (3) dark gray, homogeneous calcareous claystone ("black shale" turbidites), and (4) sandy-siltstone turbidites (Fig. 3). The laminated marly limestone and the bioturbated limestone constitute the autochthonous pelagic sedimentation and commonly occur as cyclic alternations of organic-carbon-rich laminated and organiccarbon-poor bioturbated intervals with gradational transitions. The relative proportions of laminated to bioturbated limestone vary considerably through the section; the ratio generally reflects the average clay and organic matter content of the pelagic sedimentation.

Beginning in the upper part of Core 603B-76 (midValanginian) and continuing to the top of the formation, the carbonate cycles are interrupted by thin beds of the dark-colored homogeneous claystone and thicker siltstone and sandstone turbidite beds. The claystone layers are interpreted as fine-grained turbidites because of their distinctive composition, their random, spasmodic insertion into the rhythm of the pelagic carbonates, without any effect on the cyclic pattern, the presence of a thin silt streak at the base of most layers, and the bioturbation at the top of some layers. Similar homogeneous claystone constitutes the uppermost portion of many of the siltstone turbidites, which occur in Cores $603 \mathrm{~B}-71$ to -45 , although in most places the fine-grained upper layer of such silty turbidites is absent. The siltstone turbidites are most abundant in Cores 603B-67

\footnotetext{
${ }^{5}$ Because of a $15^{\circ}$ deviation of the drill string from vertical, the actual stratigraphic thickness of the drilled Blake-Bahama Formation is about $340 \mathrm{~m}$.

${ }^{6}$ In the systematic sediment classification used on Leg 93 (Introduction and Explanatory Notes, this volume), the terms "marl" and "marly limestone" were replaced by either "nannofossil claystone" (50-70\% clay in smear slide descriptions) and "clayey nannofossil limestone" (30-50\% clay). As used in this paper, "marly limestone" consists of $25-50 \%$ clay. The term "chalk" (semilithified carbonate) will not be used.
}

through -45 , with a peak of massive beds of unconsolidated sand in Cores 603B-48 to -45 (upper Barremian to lowermost Aptian). Redeposited beds, including both homogeneous claystone and siltstone turbidites, constitute approximately $60 \%$ of the sediments between Cores 603B-75 and -44; the ratio of the net thicknesses of siltstone turbidites to homogeneous claystone layers is approximately $2: 1$. This portion of lithologic Unit $\mathrm{V}$ was denoted as Subunit VA (see Fig. 2). The turbidites are interpreted as part of a submarine fan complex that was active during the Hauterivian and Barremian. Sarti and von Rad (this volume) suggest that the unconsolidated sands correspond to a rapid input of shelf sand after a drop in sea level during the late Barremian or early Aptian (see also Wise and van Hinte, this volume).

\section{SEDIMENTARY STRUCTURES, TEXTURES, AND MICROFACIES}

\section{Cycles}

The typical pelagic facies within the Blake-Bahama Formation at Site 603 consists of alternations of laminated marly limestone and bioturbated limestone with an average frequency of about 2-3 cycles per meter of pelagic sedimentation (Fig. 4). These two structures, laminated and bioturbated, generally reflect the ratios of clay to carbonate and of organic matter to carbonate. All sediments with either greater than $80 \% \mathrm{CaCO}_{3}$ or less than $0.5 \%$ organic carbon are bioturbated, whereas sediments with either less than $65 \% \mathrm{CaCO}_{3}$ or greater than $1.0 \%$ organic carbon are laminated (Table 1; details of these characteristics will be presented later). The correlation between the contents of clay or organic matter and the occurrence of laminated or bioturbated structures need not imply cause and effect; it is possible that both are independent effects of another external cause.

The laminated sediments generally display a second, higher-frequency cyclicity (on a scale of 5 to $20 \mathrm{~cm}$, called "minor cycles" by Cotillon and Rio, 1984), which consists of clay- and organic-matter-rich and -poor intervals manifested as changes in darkness of the sediment (Fig. 4 and 5). These minor variations appear in the relatively homogeneous bioturbated intervals as changes in the degree of bioturbation or darkness and as the partial development of laminations (Fig. 4). Cotillon and Rio (1984) used the relative frequency of these minor variations as a correlation tool within the Blake-Bahama Formation and between the Blake-Bahama Formation and similar Lower Cretaceous cyclic carbonates in the Gulf of Mexico and in southeastern France; the correlation of such minor variations may extend even to coeval sediments in the Pacific (Cotillon, 1984, 1985).

On a larger scale, the ratio of laminated to bioturbated intervals and the "amplitude" of the cycles (relative differences in structures and color) varies considerably from core to core (Fig. 2). In general, the greater the relative thickness of the bioturbated intervals, the more dramatic is the difference in color, owing to greater bulk differences in content of organic matter and of clay. Probably some of this contrast between laminated and bio- 


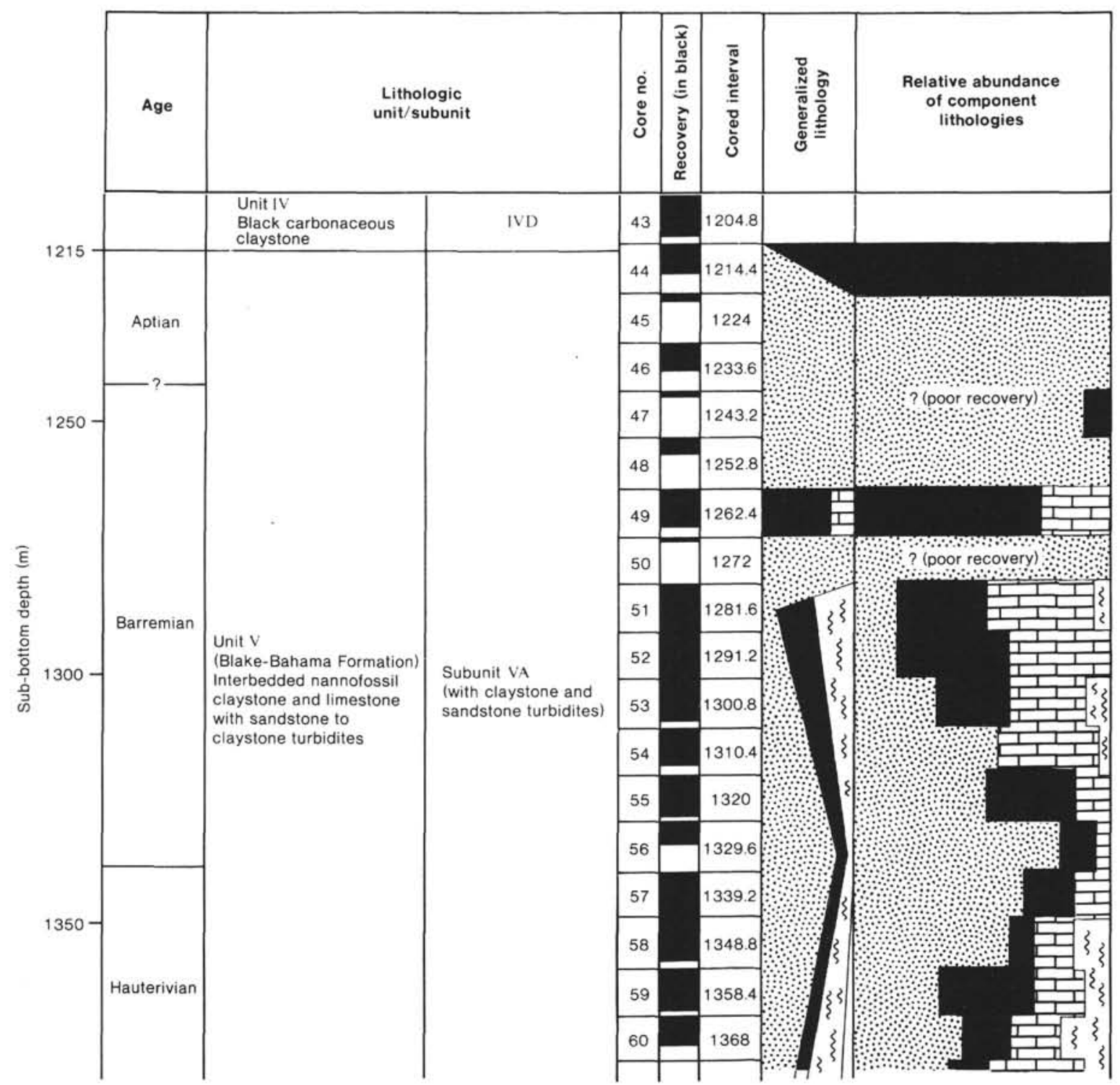

Figure 2. Stratigraphy of the Lower Cretaceous in Hole 603B. The estimated percentages of pelagic carbonates (laminated and bioturbated structures) and of clastic turbidites (claystone and sandy siltstone) within each core are indicated. Age assignments are from palynology (Habib and Drugg. this volume).

turbated beds is the result of differential compaction and of diagenetic enhancement by preferential carbonate dissolution in the laminated intervals and reprecipitation in the adjacent bioturbated intervals. A compilation of these larger-scale facies variations, which are correlatable over a large region, will be presented in the concluding section of this paper.

In summary, the pelagic sediments within the BlakeBahama Formation exhibit "cycles" or variations in laminated to bioturbated structures at several scales, from less than $5 \mathrm{~cm}$ to greater than $50 \mathrm{~m}$.

\section{Laminated Marly Limestone}

At Site 603, the laminated intervals are generally thicker than the bioturbated intervals. The average laminated sediment is marly nannofossil limestone $\left(72 \% \mathrm{CaCO}_{3}\right.$ by weight) ${ }^{7}$, which is gray with a brownish tint (color $5 \mathrm{Y} 5 / 1$ ). The carbonate content varies from $50 \%$ to $85 \%$, and the color ranges from dark gray $(\mathrm{N} 3,5 \mathrm{Y} 3 / 1)$ to light gray $(\mathrm{N} 7,5 \mathrm{Y} 7 / 1)$. Darker colors are caused by finely disseminated organic matter and pyrite.

The laminated structure consists of alternations of clay-rich and clay-poor sediment on a sub-millimeter scale (Fig. 5). The clay-rich laminae are also enriched in organic matter and fine mica. Individual laminae are generally continuous across the core width $(6 \mathrm{~cm})$, but there are many exceptions of discontinuous, irregular, con-

\footnotetext{
${ }^{7}$ The sediment classifications used in the site chapter and core-by-core lithologic deThe sediment classifications used in the site chapter and core-by-core lithologic de-
scriptions (this volume) were based entirely on shipboard estimates of the percentages of constituents in smear slides. Later carbonate analyses (Meyers, this volume; Appendix II, this volume) have shown that the percentages of clay in the smear slides were greatly overestimated. None of the laminated intervals are "calcareous claystone," as stated in the site chapter
} 


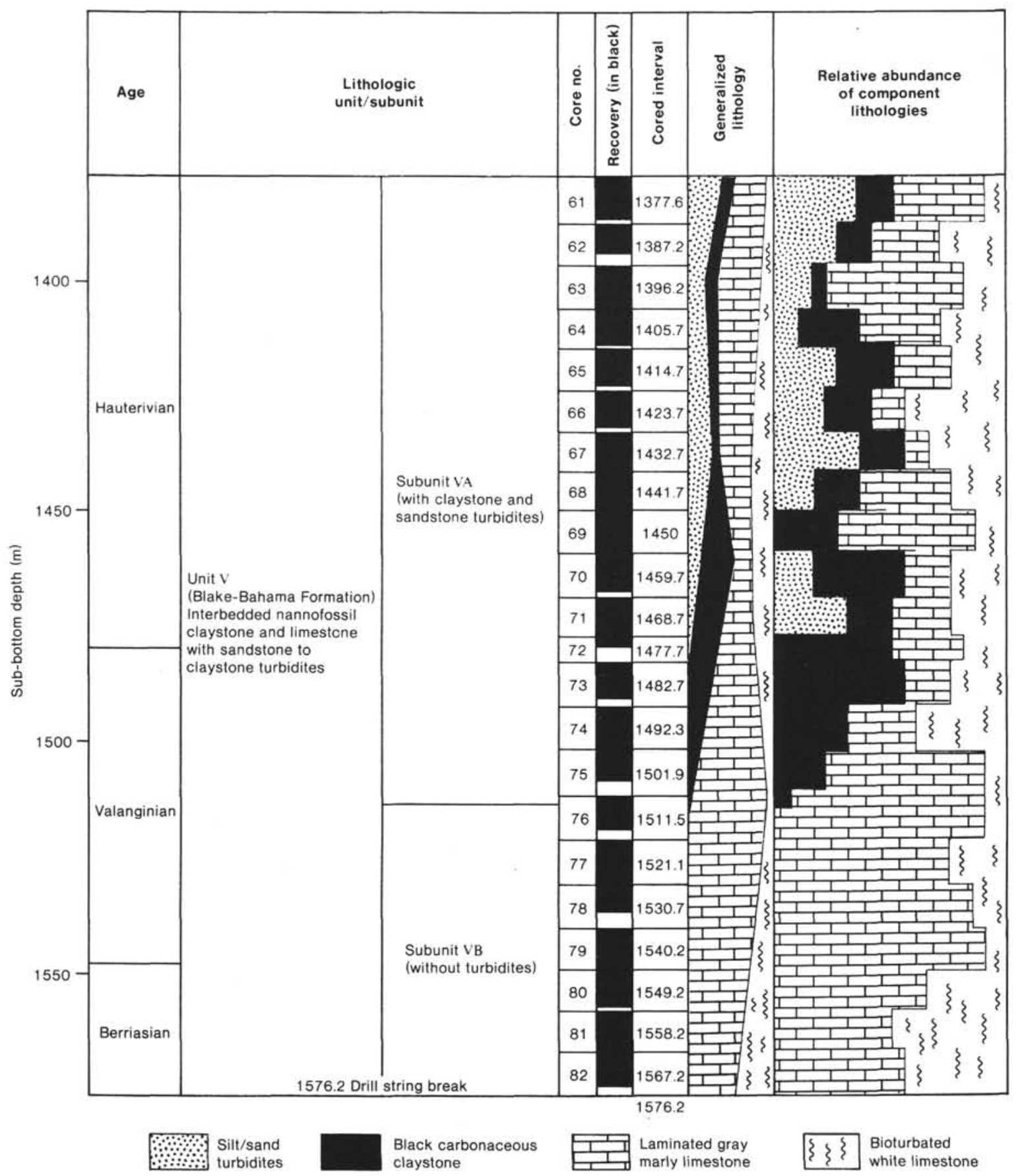

Figure 2 (continued).

verging, and lenticular laminae. In the lighter-colored (more carbonate-rich) types of laminated sediment, the laminae tend to be thicker (as much as $1 \mathrm{~mm}$ ) and less distinct (Fig. 5).

In thin section, the typical laminated, marly limestone consists of clayey micrite. Clay content ranges from about 20 to $40 \%$. Montmorillonite is the dominant miner$\mathrm{al}$, and chlorite and kaolite are present in trace amounts. Organic material is common (2-10\%), mainly in the form of terrigenous plant debris (Fig. 6; Table 2). Pyrite (2$5 \%)$ and collophane and fish debris (1-3\%) are other common constituents. Quartz, muscovite, and mollusk fragments are rare $(<1 \%)$.

Laminations are generally less distinct in thin section than in the cut core surface. The darker laminae appear as banded concentrations of subparallel, opaque particles (organic matter and pyrite) (Fig. 6). Such laminae average about 0.2 to $1.0 \mathrm{~mm}$ in thickness and have diffuse boundaries to the more micrite-rich bands.

The micrite commonly has a clotted or irregular, flattened-lenticular, "microflaser" texture (Fig. 7). Such en echelon microflasers are about $0.05 \mathrm{~mm}$ in thickness and 


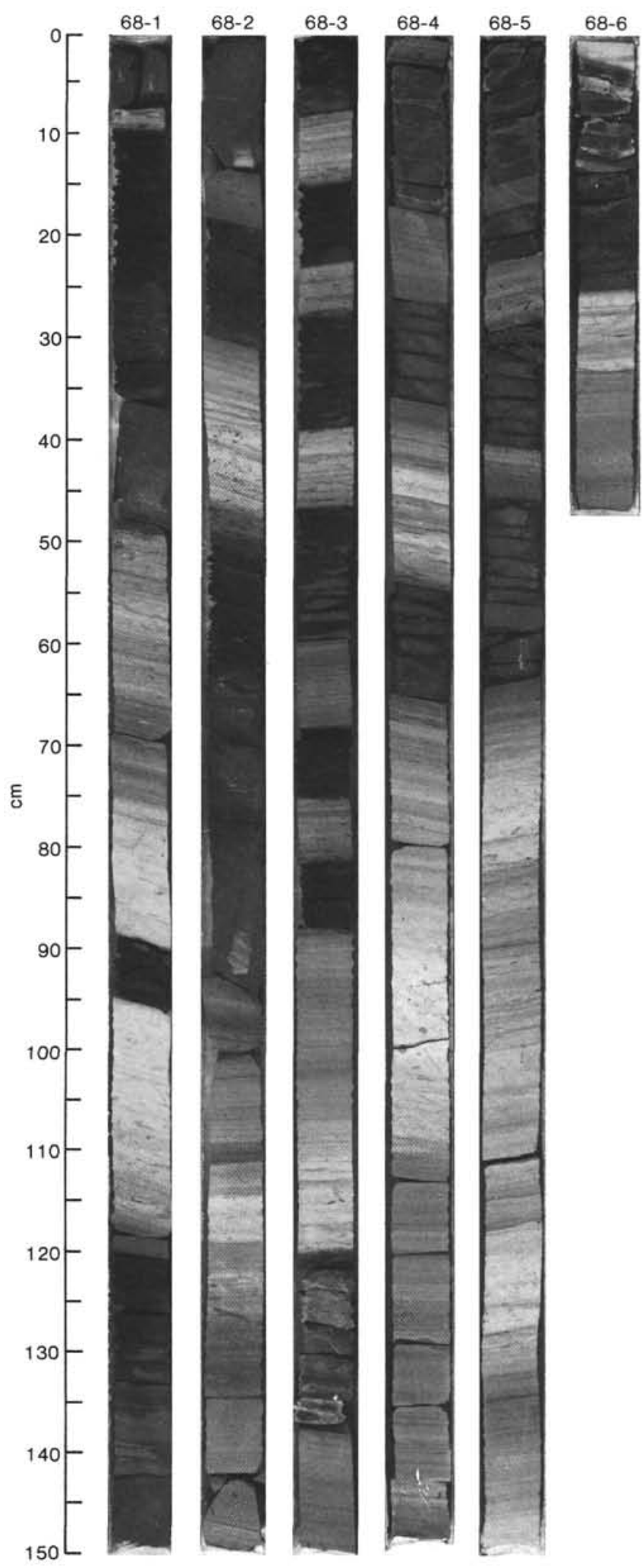

Figure 3. Typical core of Lower Cretaceous sediments from Hole 603B displaying alternations of laminated, gray, marly limestone and light gray to white, bioturbated limestone. These alternations are interrupted by black, homogeneous claystone and gray, graded siltstone turbidites. The apparent inclination of beds is an artifact of the $15^{\circ}$ deviation from vertical of Hole 603B. Core 603B-68; lower Hauterivian.

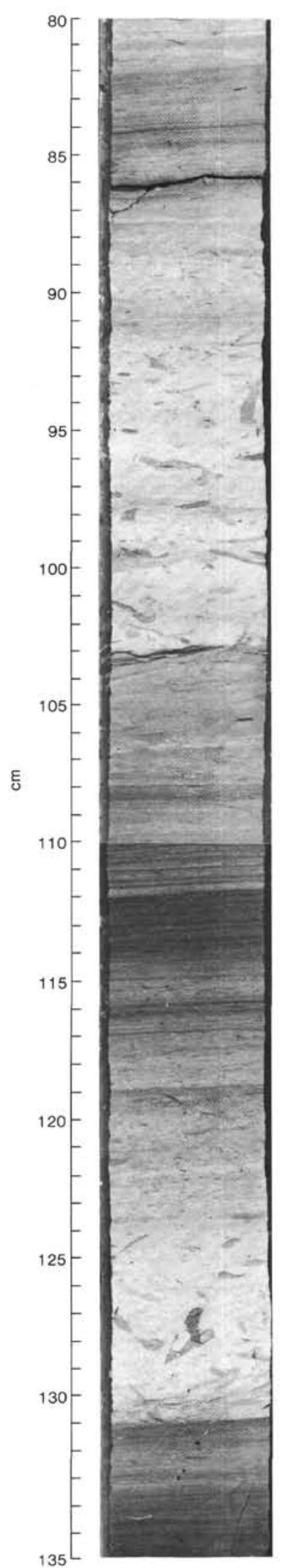

Figure 4. Two closely spaced major alternations of laminated, marly limestone and bioturbated limestone containing "minor cycles" of variable degrees of bioturbation and of partial development of laminations. Sample 603B-74-4, 80-135 cm; uppermost Valanginian. 
Table 1. Mean carbonate and organic carbon contents of lithologies, Blake-Bahama Formation, Site 603.

\begin{tabular}{|c|c|c|c|c|}
\hline Texture & $\begin{array}{l}\text { Darkness } \\
\text { value }^{\mathrm{a}}\end{array}$ & $\mathrm{CaCO}_{3}$ & Organic carbon & $N$ \\
\hline $\begin{array}{l}\text { Dark claystone } \\
\text { turbidites }\end{array}$ & $2-4$ & $19.0 \pm 8.3$ & $1.60 \pm 0.46$ & 47 \\
\hline \multirow{5}{*}{$\begin{array}{l}\text { Laminated } \\
\text { marly limestone }\end{array}$} & 3 & 66 & 2.4 & 1 \\
\hline & 4 & $67 \pm 10$ & $1.64 \pm 0.5$ & 13 \\
\hline & 5 & $76 \pm 7$ & $1.15 \pm 0.6$ & 18 \\
\hline & 6 & $75 \pm 10$ & $1.00 \pm 0.6$ & 6 \\
\hline & Mean & 72.4 & 1.33 & \\
\hline \multirow[t]{5}{*}{ Transitional } & 4 & $67 \pm 10$ & $0.4 \pm 0.1$ & 2 \\
\hline & 5 & $69 \pm 9$ & $0.4 \pm 0.3$ & 9 \\
\hline & 6 & $77 \pm 5$ & $0.26 \pm 0.12$ & 12 \\
\hline & 7 & $79 \pm 3$ & $0.3 \pm 0.3$ & 3 \\
\hline & Mean & 73.7 & 0.32 & 26 \\
\hline \multirow{4}{*}{$\begin{array}{l}\text { Bioturbated } \\
\text { limestone }\end{array}$} & 6 & $78.5 \pm 6.5$ & $0.19 \pm 0.10$ & 12 \\
\hline & 7 & $78.5 \pm 4.7$ & $0.14 \pm 0.07$ & 8 \\
\hline & 8 & $86.3 \pm 4.2$ & $0.14 \pm 0.10$ & 7 \\
\hline & Mean & 80.5 & 0.16 & 21 \\
\hline
\end{tabular}

${ }^{\mathrm{a}}$ From Munsell color chart $(1=$ black, $10=$ white $)$.

$0.5-1.0 \mathrm{~mm}$ in diameter. Variations in the size, shape, and definition of such micrite microflasers also occur in bands about $0.5 \mathrm{~mm}$ wide; these bands contribute to the macroscopic laminated structure. These flattened micrite blebs have been reported at other DSDP sites penetrating the Blake-Bahama Formation and the similar Lower Cretaceous facies in the Gulf of Mexico (Sites 535 and 540). They are considered to be evidence of a pelletal origin of the micrite (e.g., Patton et al., 1984; Cotillon and Rio, 1984). Most of the fine-grained carbonate in deep-sea sediments arrives at the bottom in the form of fecal pellets, so a similar pelletal origin of micrite in the Blake-Bahama Formation is to be expected. The highly elongate nature of most of these pellets is attributed to burial compaction and plastic deformation (e.g., Patton et al., 1984), but undoubtedly there was also significant diagenesis associated with lithification, which may have produced a microflaser texture and possibly boudinage effects during compaction (Cotillon and Rio, 1984). Bands of well-defined deformed pellets or microflasers in a relatively clay-rich matrix can form the darker laminae. This type of lamination has diffuse transitions between light- and dark-colored bands.

Thus the dark laminae in the sediment can result either from bands enriched in clay and opaques, from bands of en echelon elongate lenses of micrite in a clayrich matrix, or from a combination of both processes. In any case, the original sediment probably had small primary differences in clay and opaque content on a submillimeter scale; these were enhanced by differential compaction and by carbonate dissolution/reprecipitation accompanying lithification. The warping of laminae around ammonite aptychi or Inoceramus fragments (Fig. 8) indicates that such laminae cannot be entirely a diagenetic phenomenon, but require initial fine-scale variations in the sediment.

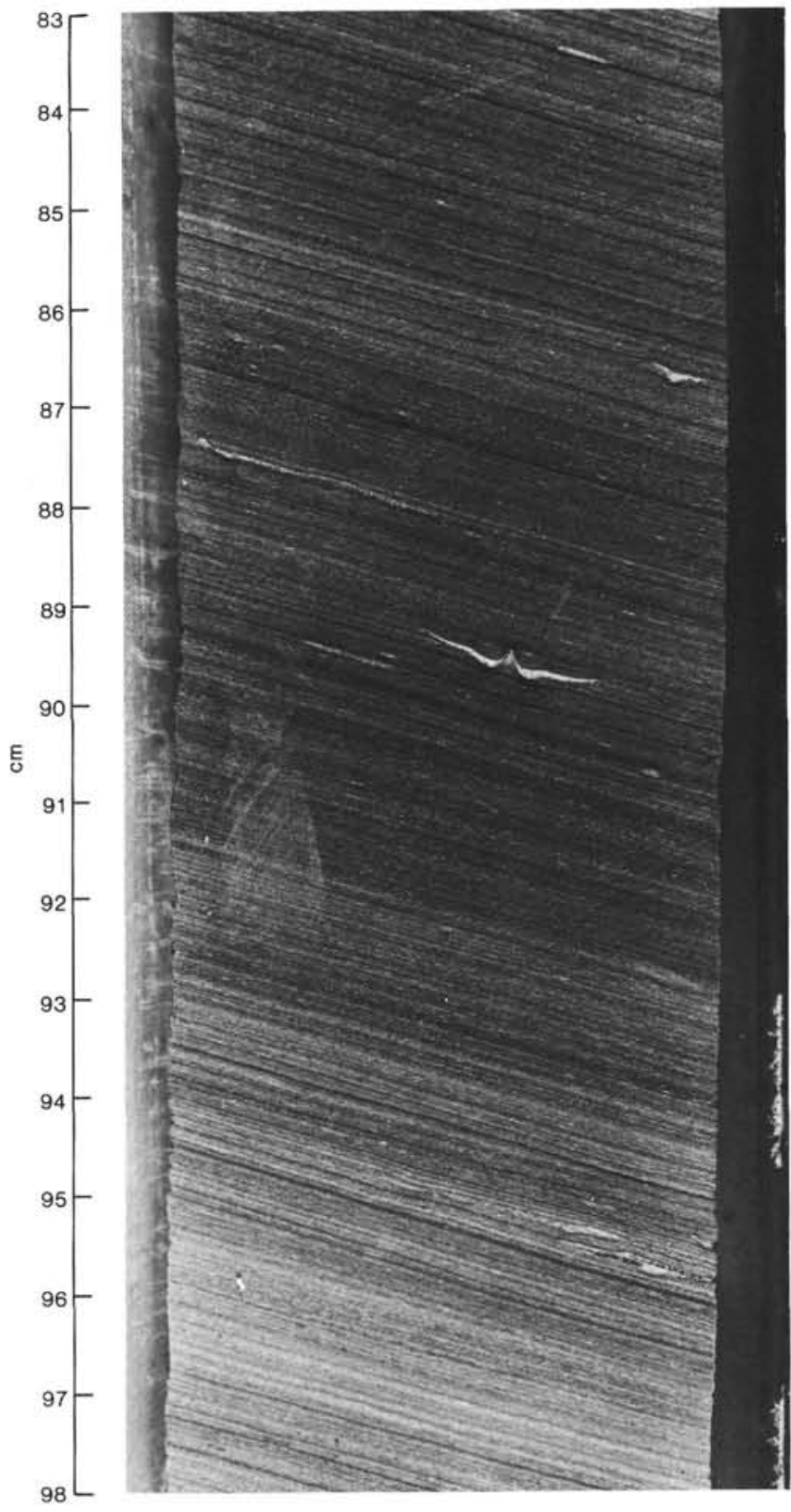

Figure 5. Typical laminated, marly limestone. The darkness, frequency, and thickness of the laminae vary from centimeter to centimeter. White and light gray, tabular objects are shell fragments (mainly Inoceramus); an ammonite aptychus is at the 90-cm level. The apparent inclination of beds is an artifact of the $15^{\circ}$ deviation from vertical of Hole 603B. Sample 603B-79-6, 83-98 cm; Berriasian/Valanginian boundary.

Very thin (1-2 mm) claystone turbidites are distinguished from clay-rich laminae in the laminated intervals by their fine-grained homogeneous texture (no radiolarians or micrite microflasers), sharp contacts, and basal silt-rich layers (Fig. 9).

The organic-matter estimates from smear slides and thin sections of the laminated limestone average about $5 \%$, which agrees with the average of $1.3 \%$ organic carbon by weight. ${ }^{8}$ The visible organic matter is primarily plant debris, including some large pieces of carbonized wood (charcoal). 

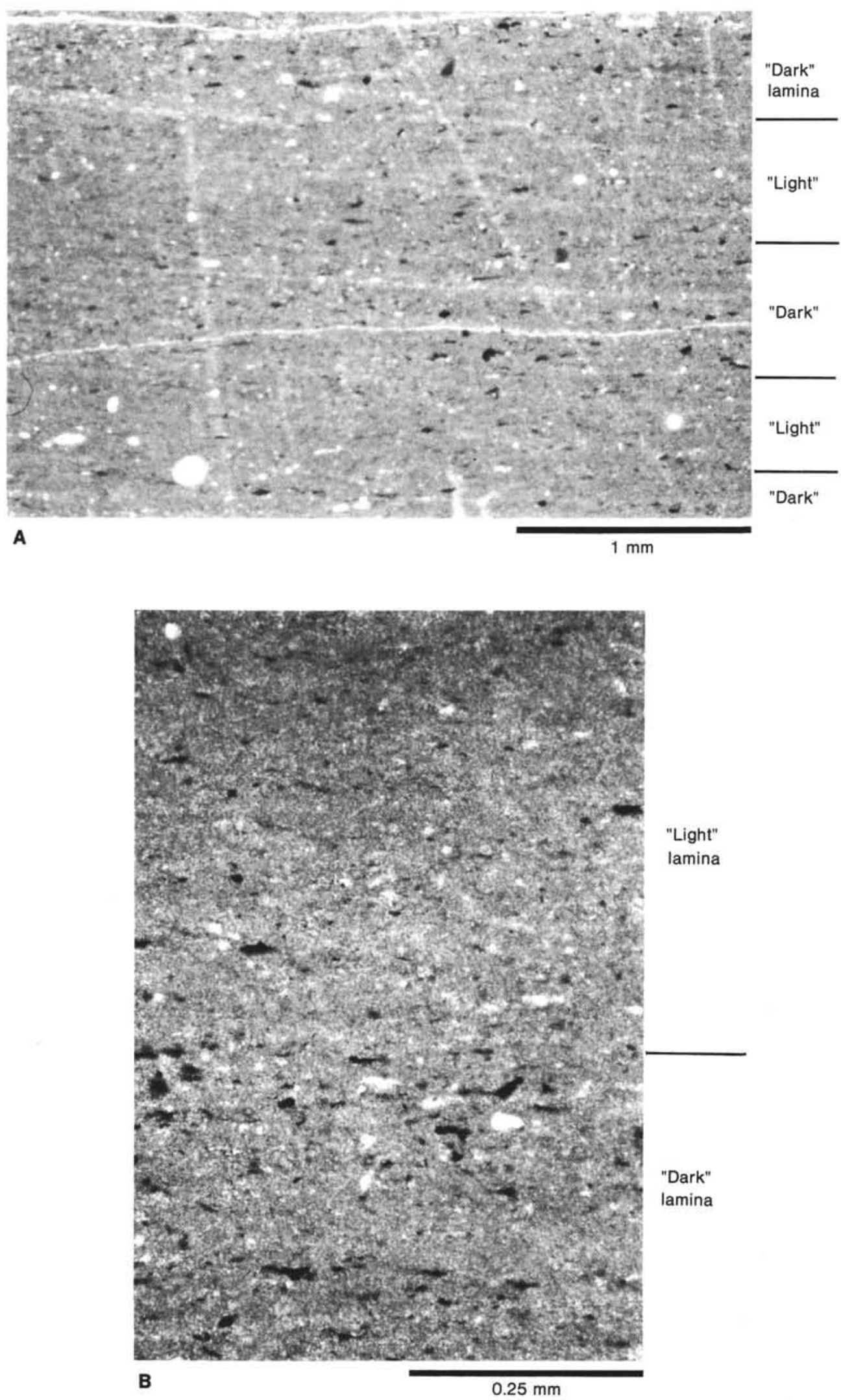

Figure 6. Micrographs of laminated marly limestone, Sample 603B-82-4, 145-147 cm; uppermost Berriasian. Light and dark laminae are caused by diffuse bands of variable concentrations of opaques (plant debris, pyrite) and clay. A. $\sim 3$ dark laminae with diffuse boundaries. B. Dark lamina in the lower half. 
Nannofossils (coccoliths and nannoconids) constitute the bulk of the carbonate fraction. The microfossil content averages only $5 \%$, of which calcified radiolarians are dominant (3-10\%). In general, the radiolarians were partially flattened then infilled by microspar. These flattened, calcified radiolarians and some of the larger micrite lenses are the cause of the "white specks" recorded in the visual core descriptions. Complete (and pyrite-replaced) radiolarian tests are rare, but pyritized fragments of radiolarian tests are common and may constitute the bulk of the pyrite in the sediment. Calcispheres ${ }^{9}$ are common at some stratigrahic levels, and foraminifers are rare.

Phosphatic fragments, presumably fish debris, comprise about $1-3 \%$ of the sediment-relatively abundant compared to other pelagic limestones. A few ammonites were recovered, but of long-ranging genera (Hoedemaeker, this volume). In the lower half of the formation (especially in the Valanginian), ammonite aptychi and Inoceramus shells are abundant.

\section{Bioturbated Limestone}

Bioturbated intervals are generally thoroughly mixed, but the last generation of burrows is visible (Fig. 10). These slanting, burial-compacted burrows range from 0.1 to $1.0 \mathrm{~cm}$ in diameter and extend downward only about $2-4 \mathrm{~cm}$. Chondrites-type burrows are also present. Turbidites within the bioturbated intervals are partially bioturbated in the upper portions, though there is some suggestion that the relative intensity of bioturbation was reduced immediately after the deposition of a thick turbidite, probably indicating the temporary disruption of the bottom fauna by such a turbidite event.

The carbonate content of bioturbated limestone averages $80 \%$, with a range of 68 to $91 \%$. The color is generally light gray (NY, 5GY7/1) with a range of medium gray (N5, N6) to nearly white (N8.5). Pyrite concretions and clusters are common, and there are streaks and patches of green coloration, probably from a fine-grained sulfide mineral. Organic material, mainly plant debris, ranges from trace amounts to $5 \%$. Quartz and mica are rare.

The microfacies of the bioturbated limestone is radiolarian-rich (10-15\%) micrite (Fig. 11, Table 2). Most radiolarians are microspar- or spar-filled molds; molds of micrite are possibly common, but the lack of a textural contrast between matrix and filling renders such "ghosts" difficult to see (Fig. 12). The more abundant spar or micrite molds of radiolarians also have a slightly patchy distribution, possibly a result of irregular mixing by bioturbation or irregularities in carbonate recrystallization of the molds. The radiolarian molds in the bioturbated intervals are generally more spherical and less flattened by compaction than molds in the adjacent laminated zones. Pyrite-replaced tests or fragments of tests tend to occur in patchy or lenticular concentrations or "stringers" within the bioturbated limestone, in addition to having a random distribution (Fig. 13). Intact

\footnotetext{
${ }^{8}$ Note the distinction between weight percent of organic carbon from chemical analyses and the volume percent of organic matter (hydrocarbons) in the sediment.

9 It is often difficult to differentiate between calcified radiolarians, "calcispheres," and ghosts of former foraminifers in thin section.
}

pyritized tests generally enclose a calcite-spar mold and display no evidence of flattening.

The preservation of radiolarians in the Lower Cretaceous limestone occurred at different stages during early diagenesis (Freeman and Enos, 1978; Robertson and Bliefnick, 1983). Pyrite replacement of a few of the siliceous (amorphous silica) tests and fragments of tests occurred first, probably in a reduction zone or level of organic decomposition and conversion of ferric iron to iron sulfides below the zone of bioturbation in the surface layer. The patchy distribution of pyritization probably reflects minor differences in Eh. The siliceous tests of all radiolarians dissolved, leaving only the unconsolidated molds - one of the curiosities of the Blake-Bahama Formation limestone is the abundance of calcified radiolarians, yet virtual absence of silica concretions. ${ }^{10} \mathrm{Par}-$ tial flattening of the molds preceded their recrystallization to spar or microspar; this compaction was greatest in the laminated intervals. Micrite molds or "ghosts" are visible only in the bioturbated limestone, whereas in the laminated intervals all radiolarian molds are replaced by spar or microspar; whether this phenomenon in the laminated intervals reflects more effective recrystallization of radiolarian molds or is the result of plastic deformation of micritized molds to the point where they are unrecognizable is unknown. The abundance of preserved radiolarians in thin sections is a minimum estimate of their original abundance in the sediment.

Calcispheres (?) occur in varying abundances up to $5 \%$ (especially in the Valanginian; Cores $603 \mathrm{~B}-82$ to -75). Sponge spicules were noted in a few thin sections. Foraminifers are rarely present. Fish debris, ammonite aptychi, and Inoceramus are rare.

\section{Transition Zones and Intervals of Partial Bioturbation}

The boundaries between laminated and bioturbated intervals generally are transition zones, 2 to $4 \mathrm{~cm}$ thick. The transition from laminated upward into bioturbated consists of an increasing degree of bioturbation downward into a prior laminated sediment (Fig. 14A). This is generally accompanied by a decrease in clay and organic-matter content. The transition from bioturbated upward into laminated consists of a gradual reduction of the frequency, size, and penetration of burrows accompanied by a darkening of color, implying increasing organic-matter and clay content (Fig. 14B). The onset of bioturbation commonly appears to have been more sudden than the cessation; this may be partially attributed to differential compaction and diagenesis.

Within the thicker intervals of laminated marly limestone are sporadic occurrences of incompletely bioturbated layers that retain a semilaminated appearance. These intervals of intermediate structure are rarely over $10 \mathrm{~cm}$ thick, are generally more carbonate-rich (and organicmatter-poor) than the adjacent laminated marly limestone, and resemble very closely the transition structure as a bioturbated facies passes upward into a laminated

\footnotetext{
${ }^{10} \mathrm{~A}$ rare and remarkable occurrence of recrystallized radiolarian ghosts with a rim cement of chalcedony (pseudomorphs after the original opal-CT) and several generations of chalcedony in the inner pore is reported from the Berriasian basal limestone (Sample 603B$82-2,147-150 \mathrm{~cm}$ ) by Thein and von Rad (in press).
} 
Table 2. Composition of selected samples from pelagic laminated marly limestone and bioturbated limestone, Hole 603B.

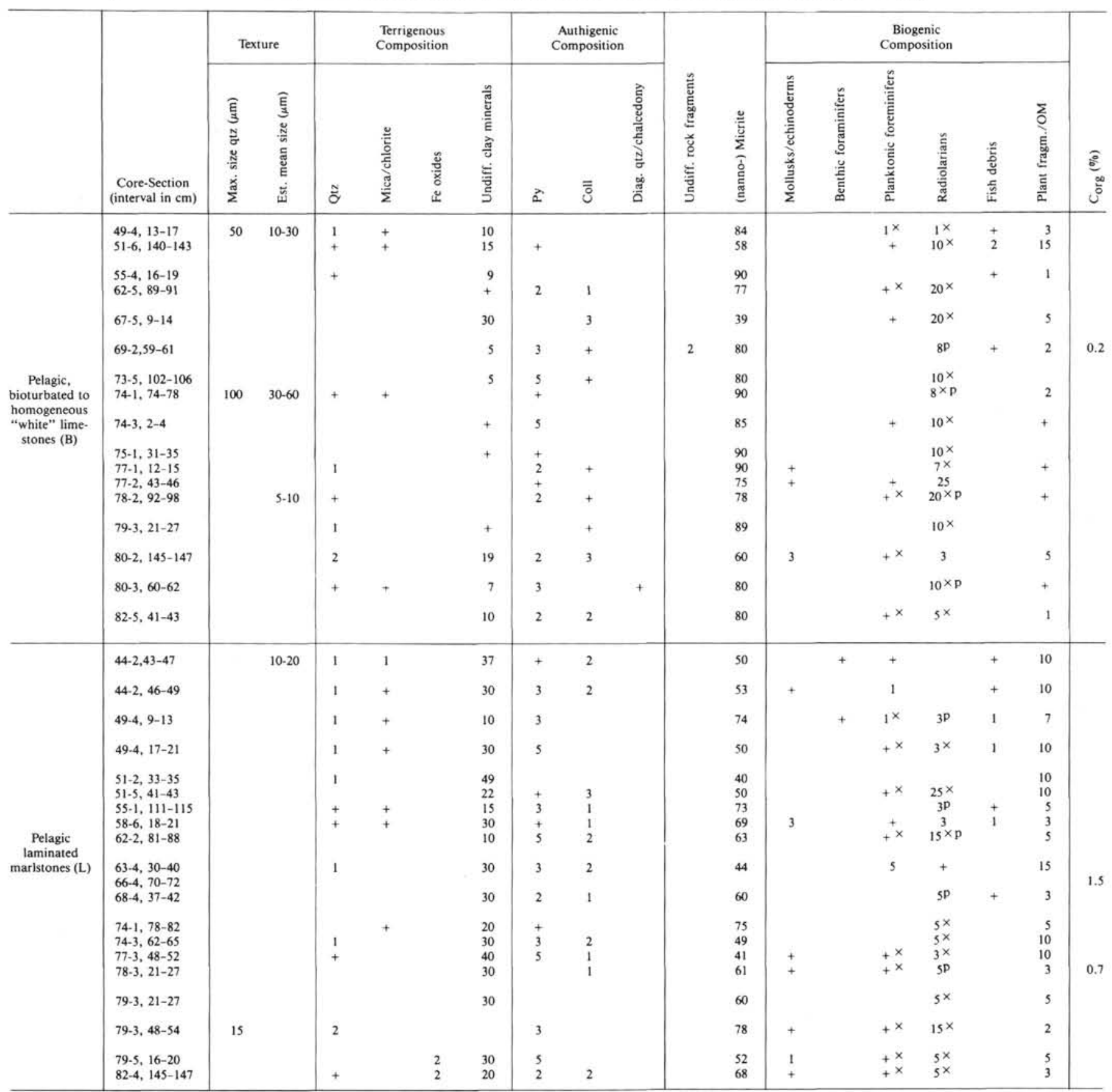

Note: Thin-section and XRD analysis carried out at the BGR, Hannover. XRD by H. Rosch: $\mathrm{CaCO}_{3} / \mathrm{C}_{\text {org }}$ by LECO induction method, data by $\mathrm{H}$. Wehner. For XRD, D = dominant ( 25 or $50 \%$ ), $\mathrm{A}=$ abundant, $\mathrm{C}=$ common $(>10 \%), \mathrm{R}=$ rare, $\mathrm{T}=$ traces $(<5 \%),(\mathrm{T})=$ ?traces. Thin-section analysis: $+=$ traces, $X=$ fossil ghosts, ca $=$ calcite, coll $=$ collophane, $\mathrm{p}=$ pyrite, qtz $=$ quartz. For foraminifers, $x=$ agglutinated. Sediment name abbreviations: $\mathrm{bt}=$ bioturbated, lam $=$ laminated, ls $=$ limestone, $\mathrm{ms}=$ marlstone, om $=$ organic matter.

one. Such intermediate structures also occur within the thicker bioturbated intervals, indicating the presence of minor cycles within the major alternations.

\section{Main Microfacies Differences between Bioturbated and Laminated Limestone}

In addition to the obvious contrast between bioturbated and laminated textures these two lithologies have several compositional, paleontological, and chemical dif- ferences which constrain models for the origin of the alternating structures:

1. Carbonate content is everywhere lower in laminated than in the adjacent bioturbated intervals (but the average reduction is only by about $10 \% \mathrm{CaCO}_{3}$ ).

2 . Organic matter (mainly plant debris) and terrigenous silt (mainly mica and quartz) are more abundant in laminated intervals than in bioturbated $(5 \%$ vs. $1 \%$, and $1-2 \%$ vs. $<1 \%$, respectively). 
Table 2 (continued).

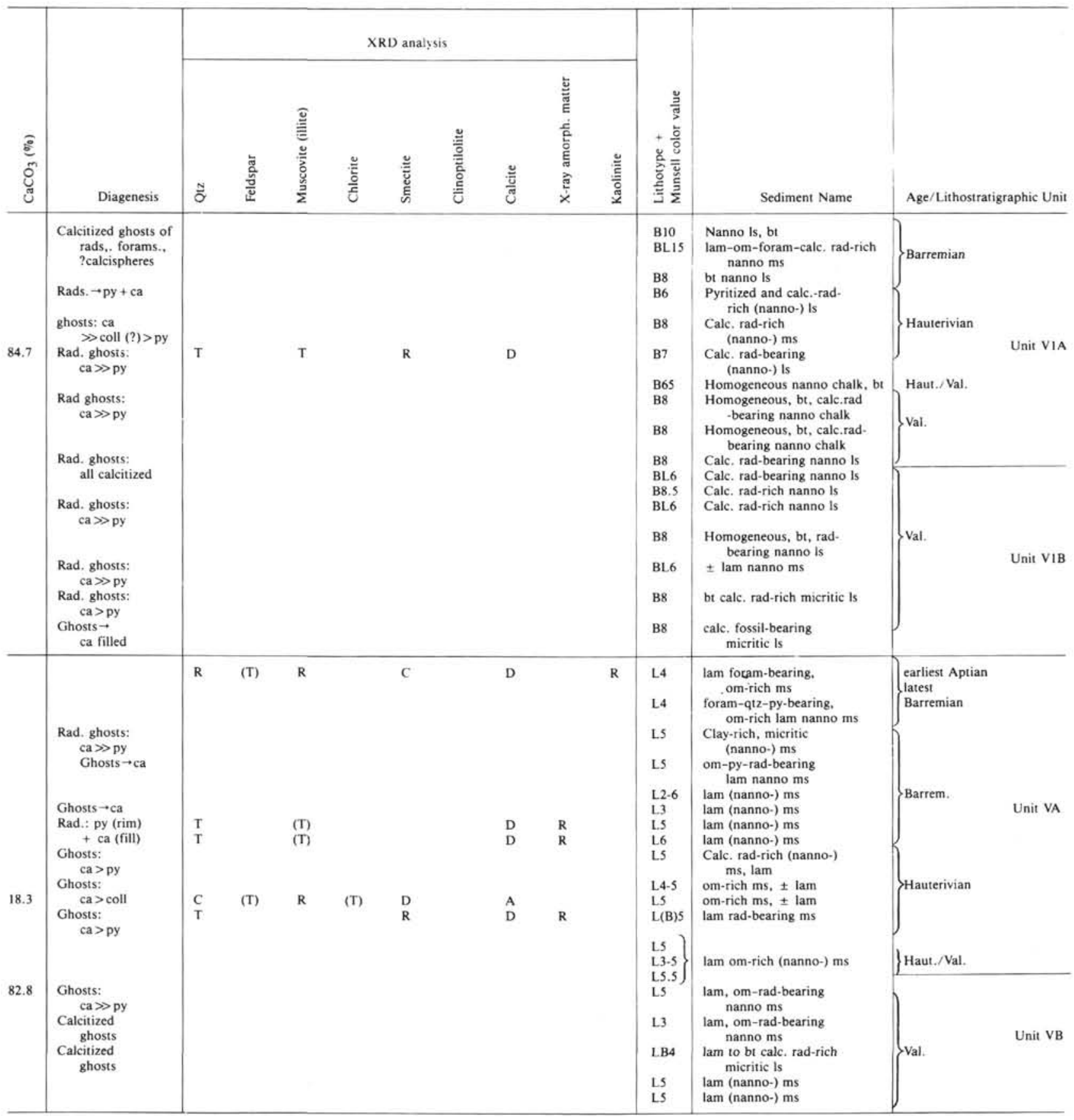

3. Radiolarians (and calcispheres) are less abundant in laminated than in adjacent bioturbated intervals $(5 \%$ vs. $10-15 \%$ ), though this general trend is less apparent where both laminated and bioturbated intervals have similar carbonate contents.

4. Radiolarian assemblages are enriched by spumellarian taxa in laminated and by nasselarian taxa in bioturbated intervals in the similar Lower Cretaceous limestone at ODP Site 638 on the Galicia margin (J. Thurow, pers. comm., 1985). This difference in assemblages may reflect either productivity or preservational differences.
5. Foraminifers are rare, but generally occur within the laminated intervals. Cotillon and Rio (1984) noted that cycles in the similar Lower Cretaceous sediments at Sites 535 and 540 in the Gulf of Mexico have a radiolarian-rich assemblage in the bioturbated limestone and a foraminifer-rich assemblage in the laminated marly limestone. This lack of foraminifers where radiolarians are abundant possibly reflects competition in high-fertility waters (M. Moullade, pers. comm., 1984).

6. Nannofossils are less abundant in laminated than in bioturbated intervals. In laminated intervals, the nan- 


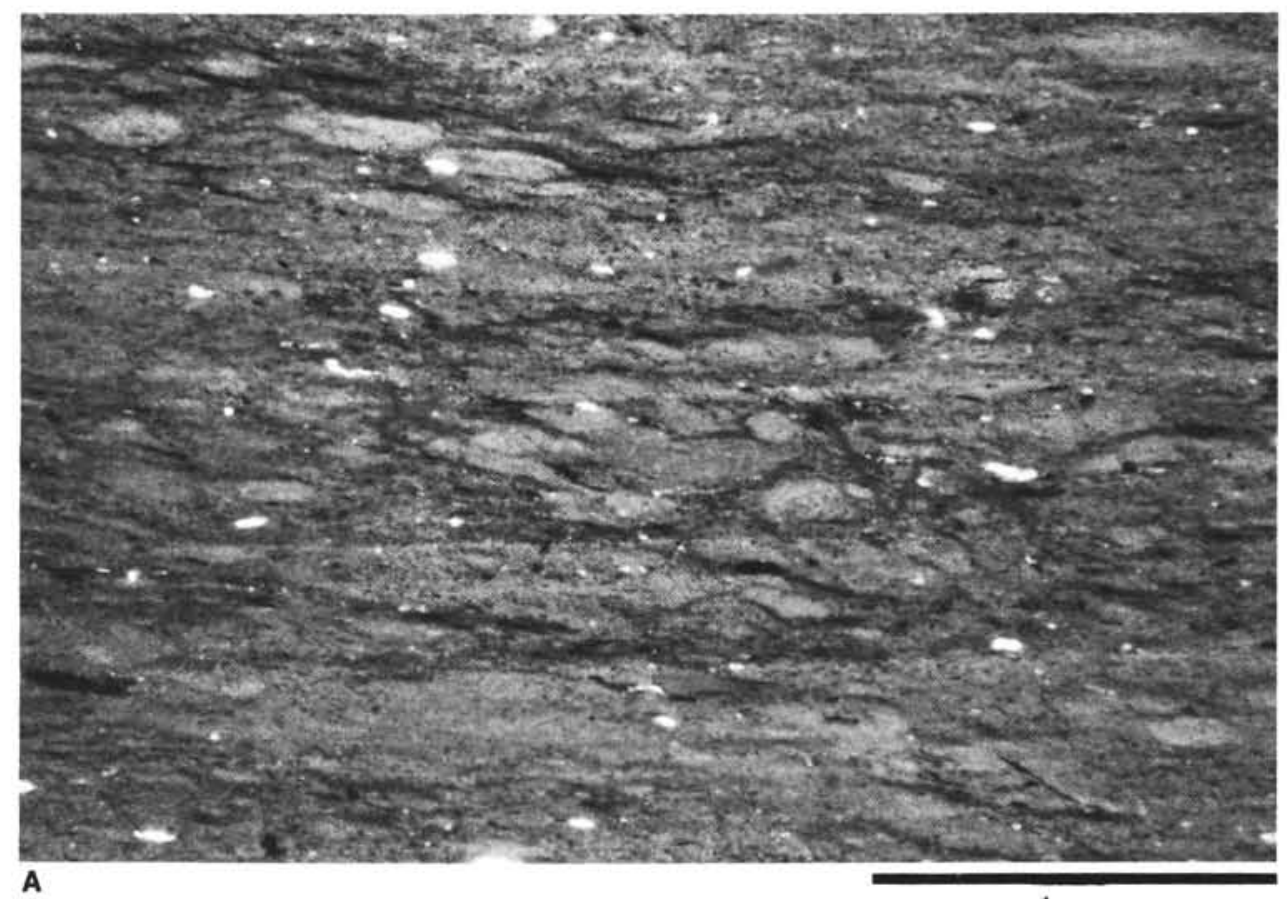

$1 \mathrm{~mm}$

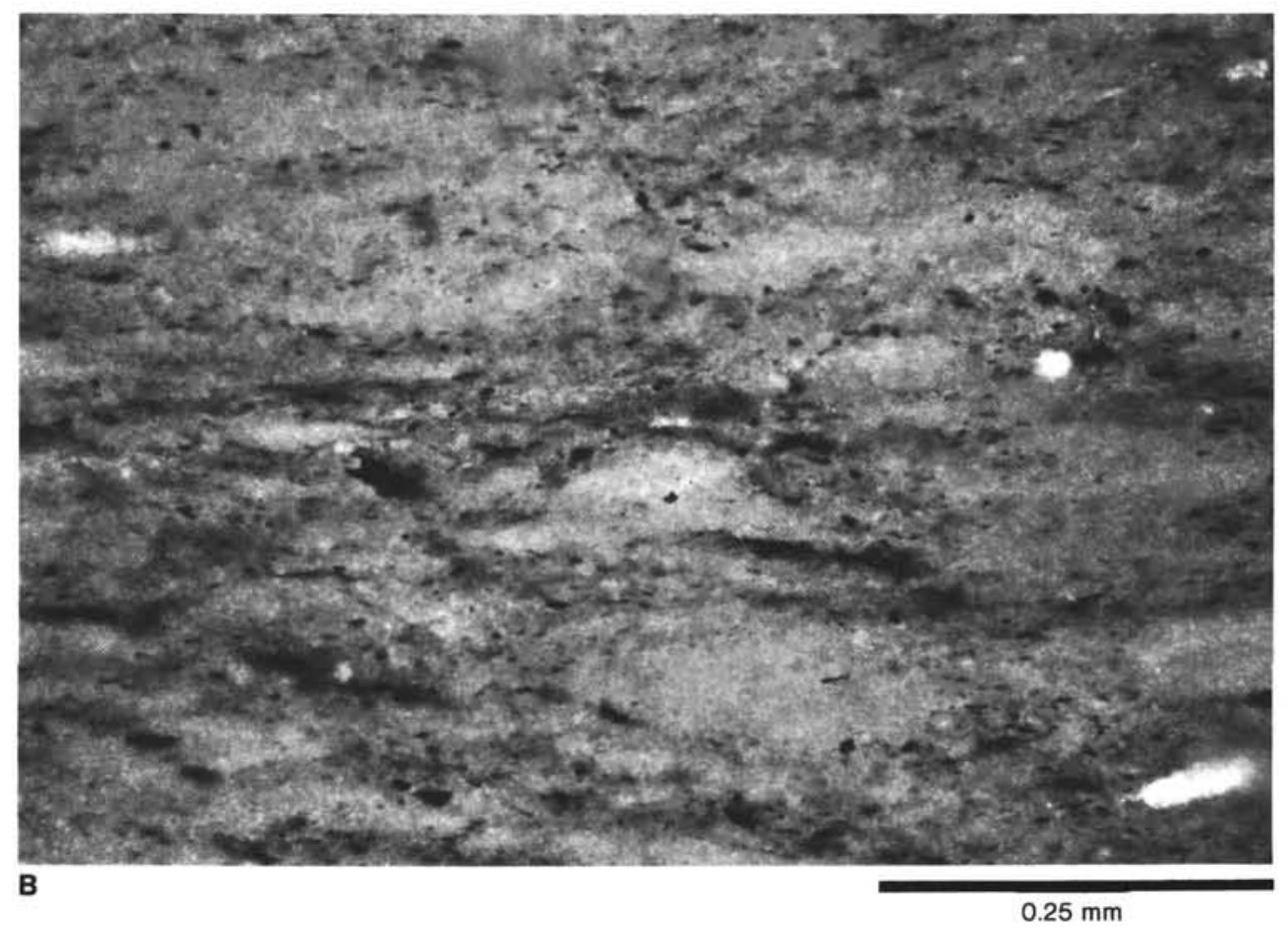

Figure 7. Micrographs of laminated marly limestone, Sample 603B-74-3, 62-65 cm; upper Valanginian. Laminae appear as bands of irregular, flattened-lenticular, "microflaser" concentrations of micrite. White specks are calcified radiolarians and phosphate fragments.

nofossils are better preserved, although they display effects of dissolution and reprecipitation (Baltuck, this volume). In bioturbated intervals, the nannofossils are more overgrown and less recognizable. Cotillon and Rio (1984) reported that laminated intervals are dominated by coccoliths, whereas bioturbated intervals are dominated by nannoconids. A similar pattern-coccoliths dominating in clay-rich beds and nannoconids in clay-poor bedswas noted in Lower Cretaceous cyclic limestone in southern France (Noël, 1968). Quantitative data on the abundances and their relationship to clay content are needed (the relative abundance of different taxa was not studied 

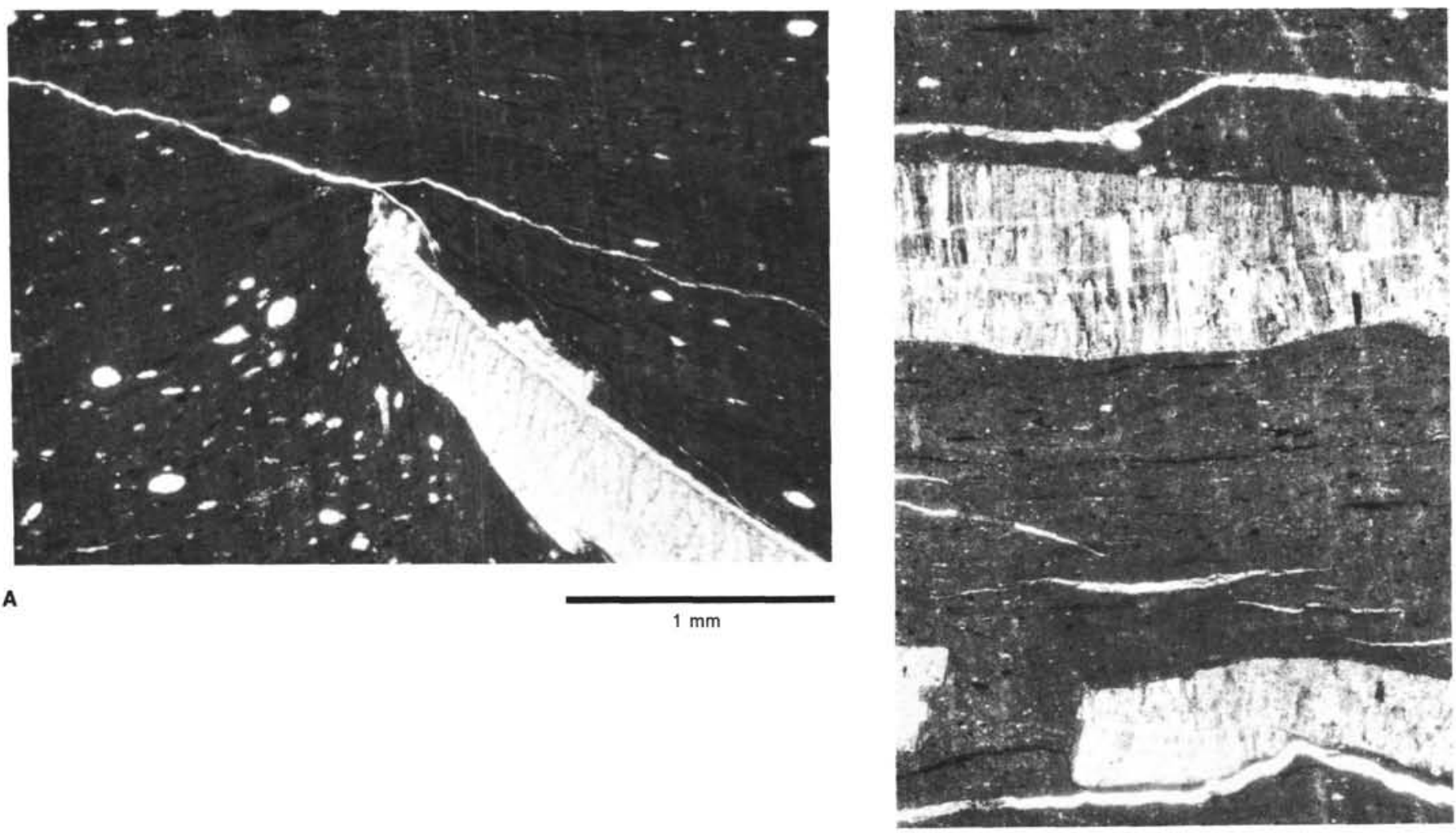

B

$1 \mathrm{~mm}$

Figure 8. A. Aptychus fragment in laminated marly limestone, Sample 603B-79-5, 16-20 cm (Berriasian/Valanginian boundary), with deformed laminae. White specks are calcified radiolarians. See Fig. 5 for a similar feature in macroscopic view. B. Inoceramus shell fragments in laminated marly limestone, Sample 603B-80-2, 145-147 cm (uppermost Berriasian) with deformed laminae.

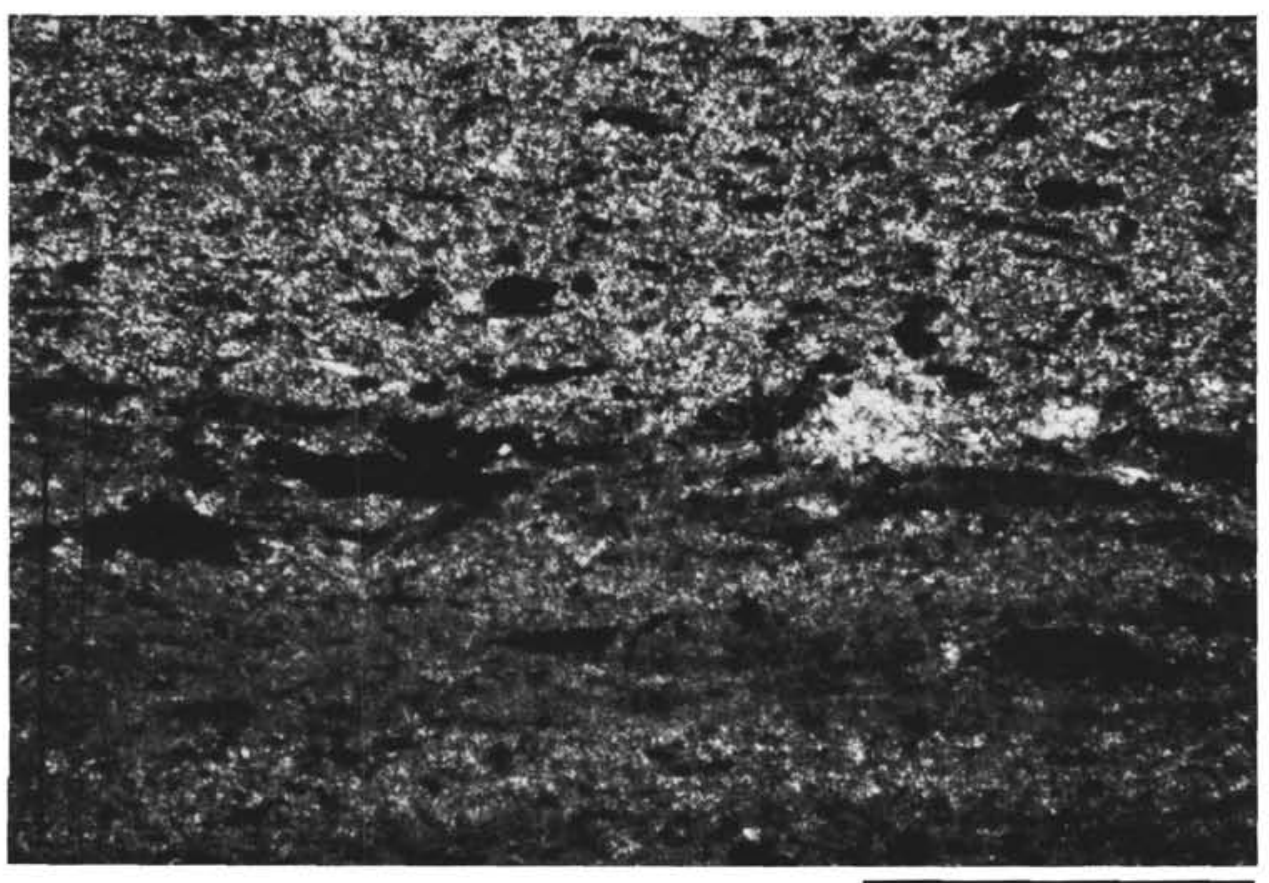

$0.25 \mathrm{~mm}$

Figure 9. Micrograph of the upper portion of claystone turbidite overlain by laminated marly limestone. Note distinct difference in composition and texture and the sharp contact. In this cross-polarized illumination, the claystone is much brighter in appearance than the limestone. Sample 603B-53-4, $117-119 \mathrm{~cm}$, mid-Barremian. 


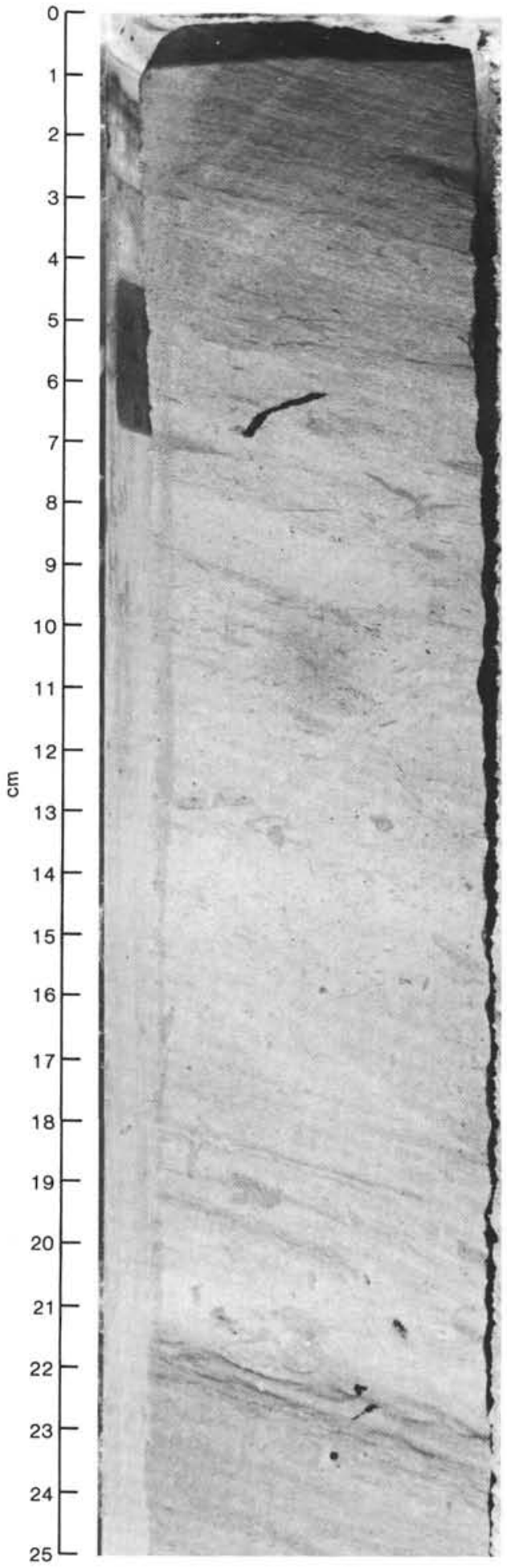

Figure 10. Typical bioturbated limestone interval with transition upward into a laminated interval. Dark streak at $6 \mathrm{~cm}$ is a pyritized burrow. The apparent inclination of beds is an artifact of the $15^{\circ}$ deviation from vertical of Hole 603B. Sample 603B-69-3, 0-25 cm; lower Hauterivian.

at Site 603). The difference in nannofossil assemblages may result from a combination of factors, including the following: (a) in limestone, nannoconids are generally more resistant to dissolution than most coccoliths (T. Bralower, pers. comm., 1985), therefore nannoconids may be preferentially preserved in the bioturbated limestone intervals; (b) in the relatively organic carbon rich, laminated intervals, the nannoconids may break up and suffer more dissolution (T. Bralower, pers. comm., 1985); (c) coccospheres may be more tolerant of turbid water than nannoconids (Noël, 1968), and so the more clayrich, coccolith-rich sediment may represent a period of relatively less clear ocean water; and (d) perhaps nannoconids were more abundant during high-fertility conditions ("nannoconid blooms") than coccoliths, and therefore are concentrated in the bioturbated, lime-rich intervals.

7. Inoceramus fragments, ammonite aptychi, and the rare ammonite specimens generally occur in the laminated intervals, rarely in the bioturbated.

8. Fish debris (angular, elongate, phosphate fragments and occasional otoliths) are more abundant in laminated than in bioturbated intervals ( $1 \%$ vs. traces).

9. The frequency of turbidites (measured as events per meter) is greater in the laminated than in adjacent bioturbated intervals. This increase in relative frequency is more apparent for dark homogeneous claystone than for silty turbidites.

\section{GEOCHEMISTRY, ISOTOPES, AND MINERALOGY}

The main components of both the laminated and bioturbated limestone are carbonate, clay and other insolubles, and organic carbon. The chemistry, mineralogy, and isotopes of these components are reported in several chapters in this volume; the main results and interpretations are summarized below.

\section{Carbonate and Organic Carbon}

\section{Carbonate Content}

Carbonate and organic carbon analyses were performed on the ship for most core sections (Meyers, Appendix II), and a supplemental set of analyses of Lower Cretaceous sediments was made by Dean and Arthur (this volume). These results were correlated to the structure (bioturbated, laminated or intermediate, or claystone turbidites) and darkness (Munsell grayness value) of each sample using the detailed visual core descriptions. The mean and standard deviation of the carbonate and the organic content for each structural-darkness type are summarized in Table 1. Analyses for which the structuraldarkness type are uncertain or highly anomalous (e.g., $60 \% \mathrm{CaCO}_{3}$ for a white limestone) were omitted.

Laminated limestone averages $72.4 \% \mathrm{CaCO}_{3}$, bioturbated limestone averages $80.5 \% \mathrm{CaCO}_{3}$, and transitional (or partially bioturbated) intervals average $73.7 \%$ $\mathrm{CaCO}_{3}$. Laminated limestone rarely has a carbonate content less than $55 \% \mathrm{CaCO}_{3}$; no bioturbated limestone has less than $68 \% \mathrm{CaCO}_{3}$. In general, the lighter-colored sediments have a higher carbonate content that the darkercolored ones of that facies; however, the ranges overlap considerably - carbonate content alone is inadequate to explain the differences in the color of the sediments. Similarly, the carbonate content of laminated and bioturbated sediments of a given darkness value is essentially 


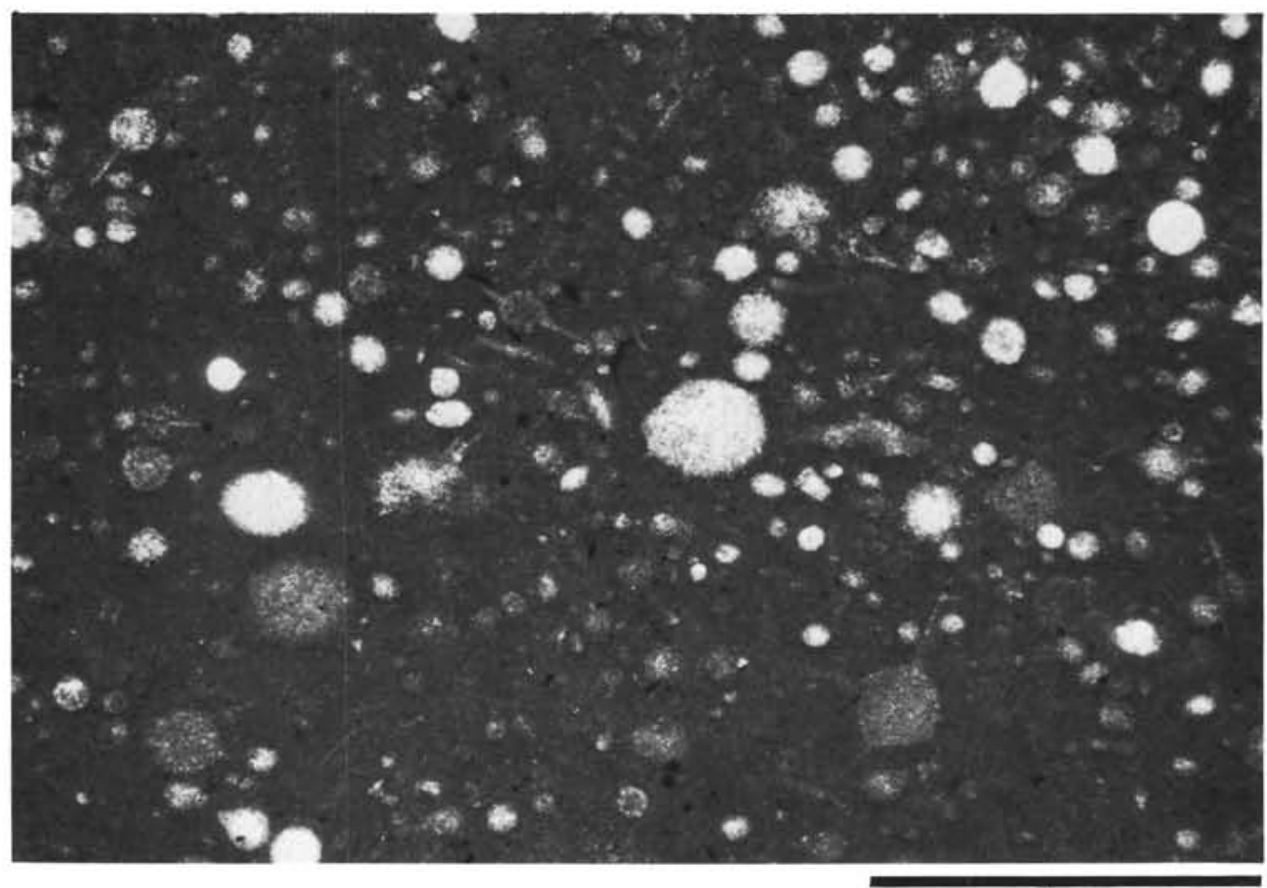

$1 \mathrm{~mm}$

Figure 11. Micrograph of typical bioturbated limestone showing radiolarian-rich micrite texture and unsorted distribution of radiolarians. Sample 603B-77-2, 43-46 cm; lower Valanginian.

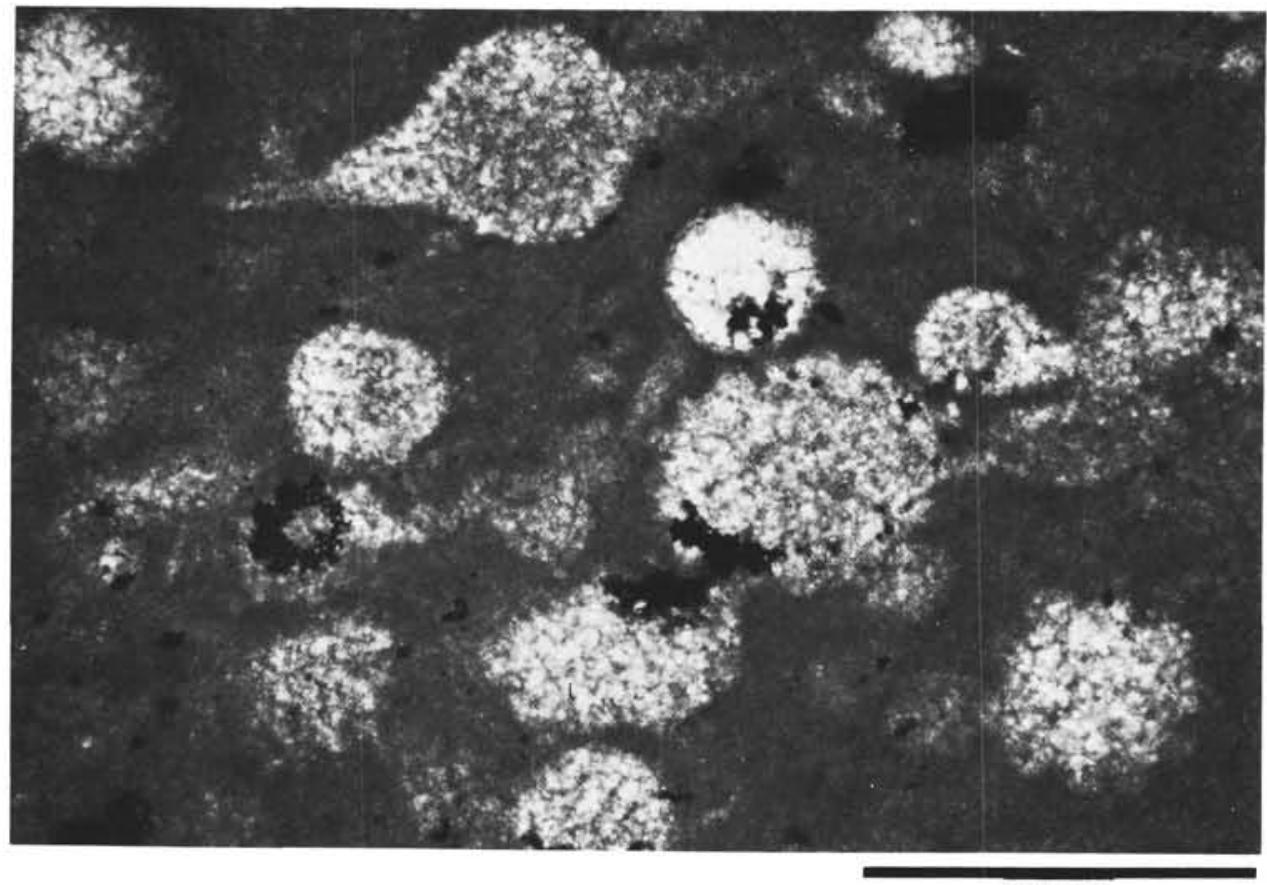

$0.25 \mathrm{~mm}$

Figure 12. Micrograph of a cluster of radiolarian molds in bioturbated limestone. Molds are replaced by spar (some with partial pyrite-replaced tests) or microspar, or are micrite "ghosts." Sample 603B-74-3, 2-4 cm; upper Valanginian.

identical. Bioturbated intervals are generally lighter-colored than the adjacent laminated intervals and therefore have slightly more carbonate, but, again, the carbonate content alone is not a guide to whether the sediment will be bioturbated or laminated.

\section{Organic Carbon}

Organic-carbon content correlates strongly with both the degree of bioturbation and the darkness value of the sediment. Laminated limestone has $1.33 \%( \pm 0.6 \%)$ or- 


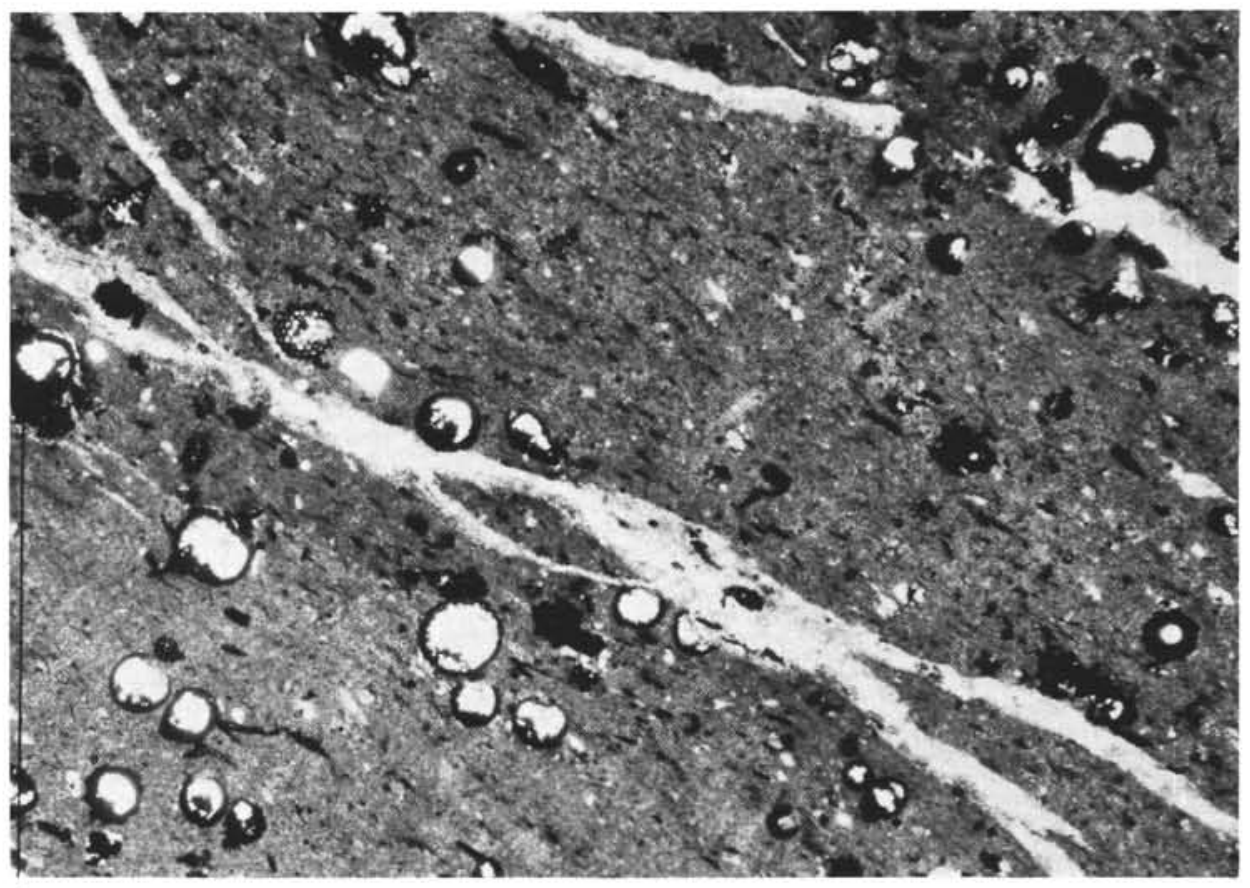

A

$1 \mathrm{~mm}$

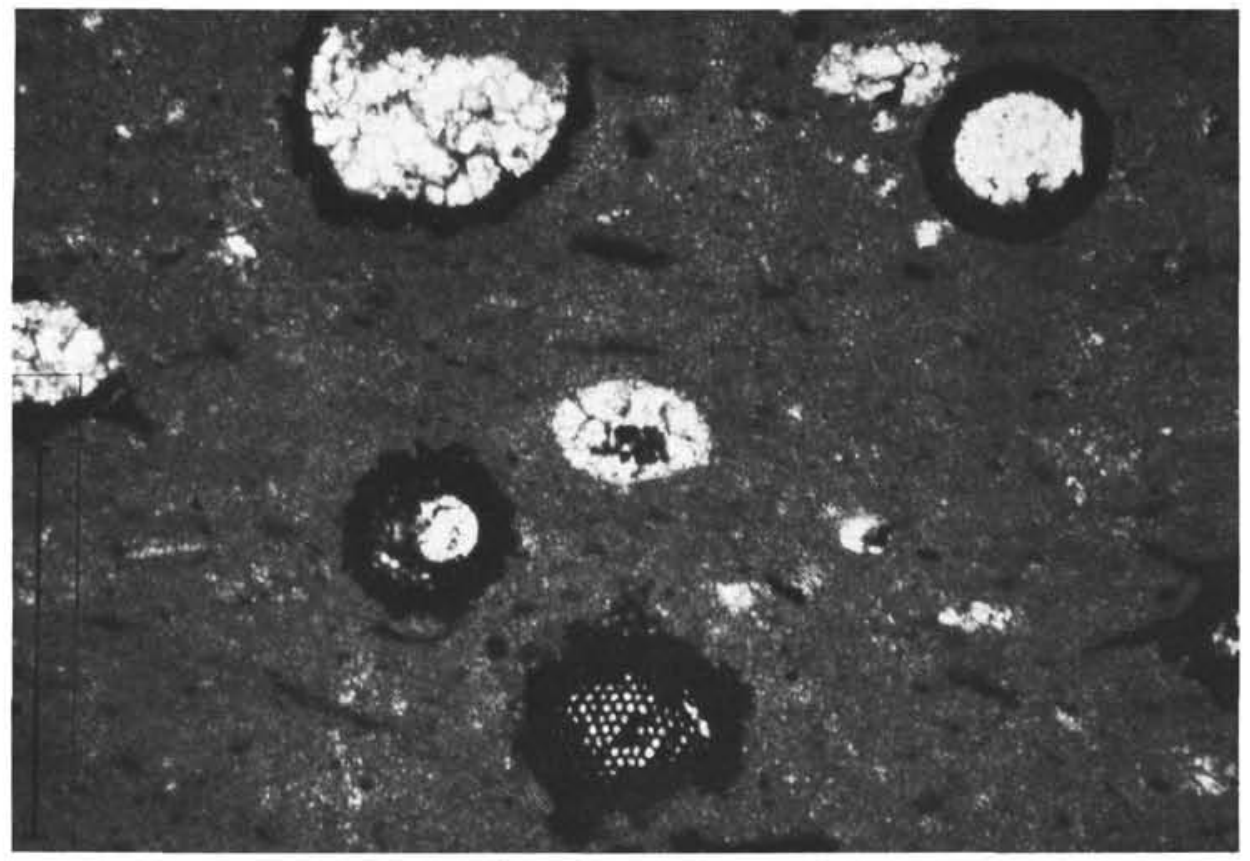

B

$0.25 \mathrm{~mm}$

Figure 13. Micrograph of a cluster of pyrite-replaced radiolarian tests in bioturbated limestone. Intact tests have a spar filling. Sample 603B-62-2, 79-81 cm; upper Hauterivian.

ganic carbon, transitional limestone has $0.32 \%( \pm 0.2 \%)$, and bioturbated limestone has only $0.16 \%( \pm 0.07 \%)$. In each of these facies, a lighter-colored sediment has less organic carbon than a darker-colored. The combination of organic-carbon content and carbonate content appears to determine the degree of bioturbation and the color of the majority of samples. Possible models to explain these relationships will be explored later.

Dark homogeneous claystone turbidites are very low in carbonate $\left(19 \% \mathrm{CaCO}_{3} \pm 8 \%\right)$ and contain the same content of organic carbon $(1.6 \% \pm 0.5 \%)$ as the darker laminated marly limestone $(1.7 \% \pm 0.6 \%)$. Therefore, 
A

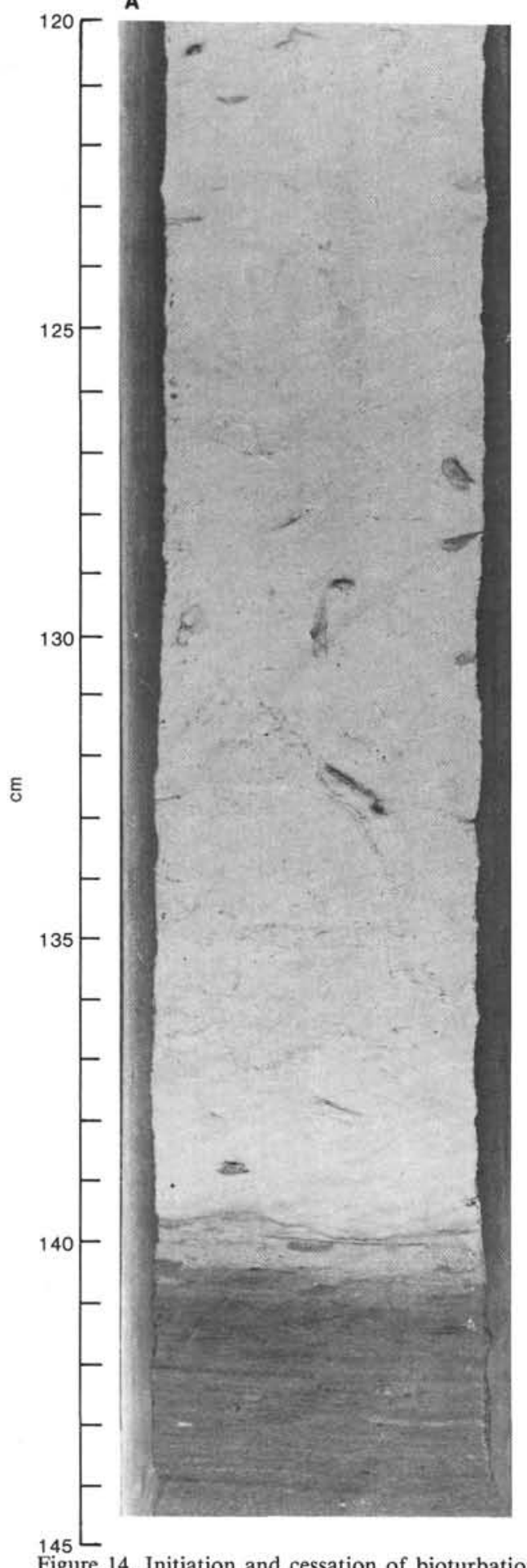

LOWER CRETACEOUS PELAGIC SEDIMENTS, SITE 603

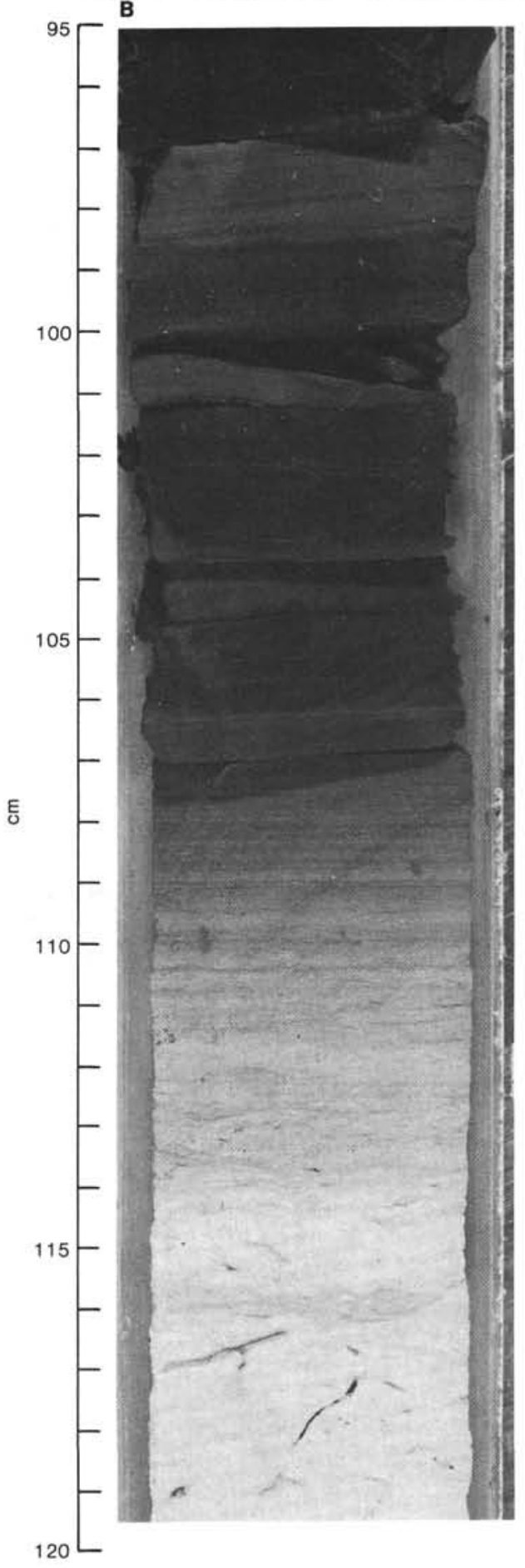

Figure 14. Initiation and cessation of bioturbation. Sample 603B-66-1, 95-145 cm; upper Hauterivian. A. Transition from laminated marly limestone upward to bioturbated limestone. Bioturbation appears to have begun relatively suddenly with early burrows extending downward into a previously laminated sediment. B. Transition from the same bioturbated limestone interval upward to laminated marly limestone. The size and depth of penetration of burrows gradually diminish and bands of light/dark appear. At the top of the photo, several dark claystone turbidites interrupt the laminated sedimentation.

the organic content relative to the clay content in the dark claystone is much less (by a factor of 2.5) than in the laminated pelagic limestone. Siltstone turbidites are generally very low in both carbonate and organic-carbon content.
The type of organic matter and its preservation were analyzed by several techniques. Visual descriptions and smear-slide and thin-section observations indicate that the macroscopic and microscopic particles of organic material are predominantly angular plant debris. Rock- 
Eval data show a strong positive correlation between the organic matter content (on a carbonate-free basis) and the hydrogen index of that organic matter; increases of organic matter over $1 \%$ total carbon are interpreted as the enhanced preservation of amorphous, hydrogen-rich, marine organic matter in the laminated sediments (Dean and Arthur, this volume). Low values of the hydrogen index $(<170 \mathrm{mg} \mathrm{HC} / \mathrm{g} \mathrm{OC})$ indicate that most of the organic matter is degraded, oxidized type III kerogen; the organic matter has low thermal maturity (Meyers, this volume).

Carbon-isotope analyses are complicated by the apparent relative ${ }^{13} \mathrm{C}$ enrichment of terrestrial vegetation $(-23$ to $-25 \%$ ) compared to marine plankton $(-27$ to $-29 \%$ ) during the Cretaceous, in contrast to the 5-6\% relative depletion observed today (Arthur et al., 1985; Dean and Arthur, this volume). Bioturbated limestone at Site 603 has an average $\delta^{13} \mathrm{C}$ value of $-25.1 \%$, and laminated intervals average $-26.0 \%$; this suggests that the laminated intervals contain a greater amount of lighter marine organic matter than the bioturbated limestone. The $\delta^{13} \mathrm{C}$ values and low oxygen indices (from RockEval) of the laminated limestone and of dark claystone turbidites are interpreted as indicating a mixture of degraded marine and terrigenous organic matter (Dean and Arthur, this volume).

The carbon/nitrogen $(\mathrm{C} / \mathrm{N})$ ratio of most carbonate samples and claystone turbidite samples is $\mathbf{3 0}$ or greater, which is interpreted as an indication that most of the organic matter is derived predominantly from land plants (Site 603 chapter, review by Meyers, and Appendix II, all in this volume). ${ }^{11}$ Sediments richer in organic matter generally have higher $\mathrm{C} / \mathrm{N}$ ratios.

The laminated and bioturbated limestones are enriched in phosphate relative to the interbedded dark claystone turbidites (average of $0.38 \% \mathrm{P}_{2} \mathrm{O}_{5}$ for limestone vs. $0.10 \%$ for dark claystone on a carbonate-free basis; Dean and Arthur, this volume); this is cited as evidence of partial preservation of marine organic matter in the carbonates, although much of this phosphate may be in the abundant fish debris in the carbonates and not associated with the organic matter.

Habib and Drugg (this volume) examined the stratigraphic distribution of types of organic matter as part of their palynological biostratigraphy of Site 603. They characterized the organic matter as terrigenous or marine-derived by the predominance of either spores or fine, granular, amorphous particles in their organic residues (after $\mathrm{HCl}$ and $\mathrm{HF}$ acid treatment). The lower Valanginian limestone is characterized by a marine organic facies ("organic unit KX1") prior to the advent of dark claystone and siltstone turbidites. This marine organic matter may have been derived from partially oxidized zooplankton fecal pellets (Rullkötter et al., this volume). The overlying fan complex has episodes of terrestrial organic and poorly developed marine organic facies (e.g., Cores 603B-50 to -53-“organic unit KX3"), although these

\footnotetext{
${ }^{11}$ In contrast to these studies, Dean and Arthur (this volume) obtained $\mathrm{C} / \mathrm{N}$ ratios of less than 10 for a set of carbonate samples, and therefore interpreted the organic matter as having a large marine component.
}

interpretations are perhaps biased by the abundance of claystone turbidites in the suite of samples.

In summary, the geochemistry of the organic-carbon fraction indicates that it is predominantly derived from terrestrial plants with an additional marine component possibly present in the laminated carbonates. Marine organic matter may be dominant in the lower Valanginian limestone. The relative contributions of marine-derived and terrigenous organic carbon to the carbonate sediments during the Early Cretaceous remain moot.

\section{Stable Isotopes of Carbonates}

Stable-isotope analyses of the bulk carbonate of the laminated and the bioturbated limestone indicate that the laminated facies is everywhere enriched in both ${ }^{13} \mathrm{C}$ (by about $0.5 \%$ ) and ${ }^{18} \mathrm{O}$ (by about $2 \% 0$ ) relative to the adjacent bioturbated intervals (Baltuck; Haggerty; both this volume).

Enrichment of ${ }^{13} \mathrm{C}$ in the laminated portion of cycles is also reported for other Lower Cretaceous carbonates by Létolle et al. (1978), Weissert et al. (1978), and Scholle and Arthur (1980). Baltuck, following the models of these previous studies, interprets the ${ }^{13} \mathrm{C}$ enrichment of the laminated intervals at Site 603 as being the result of an increase either in the productivity of the surface waters or in the preservation of marine organic matter in the sediments, or an increase in a combination of these factors. These factors would cause a preferential removal of the lighter carbon from the surface waters, thereby enriching the carbonate tests in these surface waters in ${ }^{13} \mathrm{C}$. Such a model is said to be consistent with the ${ }^{13} \mathrm{C}$ depletion of $0.5 \%$ in the organic-carbon fraction of the laminated limestone relative to the bioturbated limestone which Dean and Arthur (this volume) attribute to increased preservation of marine organic matter. The ${ }^{13} \mathrm{C}$ content of both the carbonate and organic carbon appear to decrease upsection.

The relative ${ }^{18} \mathrm{O}$ enrichment of the laminated intervals is interpreted by Baltuck (this volume) to be mainly a side-effect of the preferential dissolution of carbonate from the laminated intervals and its reprecipitation in the bioturbated limestone intervals during burial diagenesis, rather than a primary difference in the carbonate tests. Such a model is said to be supported by SEM observation of diagenesis (Baltuck, this volume). However, until mass balance calculations are available to show that this enrichment in ${ }^{18} \mathrm{O}$ is entirely diagenetic, it is possible that both factors are involved.

Haggerty (this volume) obtained oxygen-isotope paleotemperatures from four Inoceramus and one belemnite. These results, which are mainly from upper Berriasian-lower Valanginian sediments, indicate that the bottom-water temperature were at least $11^{\circ} \mathrm{C}$.

\section{Inorganic Components}

The inorganic constituents of the carbonates are primarily clay, minor amounts of pyrite, and variable amounts of mica, quartz, and other terrigenous silt. The few X-ray diffraction analyses suggest that most of the clay, at least in the laminated intervals, is smectite with some illite, kaolinite, and X-ray amorphous mat- 
ter, and that there are no major mineralogical differences between the dark claystone turbidites and the inorganic fraction of the carbonates (Sarti and von Rad; Haggerty; Holmes; and Huff; all in this volume) (Table 2 ). There is some indication of an increase in illite and kaolinite abundance upsection.

Concentrations of major, minor, and trace elements of the noncarbonate fraction of each lithology (laminated marly limestone, bioturbated limestone, and dark claystone turbidites) have been determined by Dean and Arthur (this volume). the dark claystone turbidites are (1) relatively enriched in $\mathrm{Al}_{2} \mathrm{O}_{3}, \mathrm{~K}_{2} \mathrm{O}$, and $\mathrm{TiO}_{2}$, (2) relatively depleted in $\mathrm{MnO}_{2}$ (interpreted as a greater substitution for $\mathrm{Ca}^{+2}$ in the carbonates) and most trace elements, and (3) slightly depleted in $\mathrm{MgO}$ and $\mathrm{Fe}_{2} \mathrm{O}_{3}$ relative to the carbonates. Further differences between lithologies are observed in the ratios of $\mathrm{Al}_{2} \mathrm{O}_{3} / \mathrm{TiO}_{2}$ (higher in claystone) and $\mathrm{Na}_{2} \mathrm{O} / \mathrm{K}_{2} \mathrm{O}$ (lower in claystone).

From a comparison with the geochemistry of the coeval similar facies at Site 367 near the African margin, Dean and Arthur conclude that the inorganic fraction of the carbonates at Site 603 contains a significant contribution of clastics derived from the African continent; these clastics are characterized by high $\mathrm{Na}$ and $\mathrm{Al}$ and were presumably eolian transported. Typical North America-derived clastics, characterized by low $\mathrm{Na}$ and $\mathrm{Al}$, are also present. This interpretation of the provenance of the terrigenous clastics assumes that diagenesis has not altered the elemental ratios or clay types. Prezbindowski and Pittman (this volume) found that diagenesis in siltstone turbidite beds of Hauterivian-Barremian age had significantly affected the mineralogy and associated elemental ratios.

A curious phenomenon is that some laminated and bioturbated limestones at Site 603 have unusually high concentrations of rare earth elements (and $\mathrm{Mg}$ and $\mathrm{P}$ ), whereas others do not. In general, laminated limestone has higher concentrations of trace elements than bioturbated limestone; perhaps some of these trace elements are carried (complexed) by the organic matter.

Although the magnetic properties of the limestone and claystone indicate that magnetite is the main carrier of remanant magnetization (Ogg, this volume), most of the iron probably is incorporated into pyritized radiolarian tests or other Fe-sulfides.

\section{ORIGIN OF LAMINATIONS AND OF CARBONATE CYCLES}

To this point, mainly observations and geochemical data have been presented, with interpretations and models included where appropriate. The most distinctive features of the Lower Cretaceous sediments are the alternations of laminated and bioturbated limestone. The quasicyclic alternations and laminations were described above, and possible models of the origin of these sedimentary features will now be presented. It is obvious that the bioturbated sediments indicate abundant, active bottom life. The laminated intervals, which comprise the majority of the pelagic sediment at Site 603, record periods of negligible infauna; why these sediments should be finely laminated is debated. The question of the origin of the lamination bears on the ultimate question of the origin of the cyclic changes between laminated and bioturbated limestone.

\section{Laminations}

There are some pertinent facts about these submillimeter laminations:

1. The darker laminae can result from either of two end members: (a) bands with a relative concentration of opaque particles (mainly organic matter and pyrite) and of clay and fine mica, or (b) bands with a clay-rich matrix enclosing highly lenticular and irregular pods or microflasers of micrite, or (c) a combination of both.

2 . The boundaries of light and dark laminae of either microstructure are gradational in thin section.

3. The ratios of thickness and the spacing of light and dark laminae are highly variable.

4. The thickness of the laminae varies from 0.1 to $1.0 \mathrm{~mm}$.

5. Some sets of laminae display convergence, truncation, or discontinuities, but these are atypical.

6 . Sets of laminae bend around fragments of macrofossils without an apparent change in the number of laminae present, only the spacing (Fig. 8; see also Haggerty, this volume).

7. The geochemistry of the inorganic fraction of laminated sediments is distinctly different from that of interbedded dark claystone turbidites.

The laminations are generally too narrow and closely spaced in hand specimens and are not distinct enough in thin sections to be able to collect statistics on their thicknesses and frequencies, and it has not been possible to demonstrate whether they are quasiperiodic or are random fluctuations.

Similar Lower Cretaceous laminated marl and marly limestones were analyzed at DSDP Site 534 by Robertson and Bliefnick (1983), who examined five theoretical causes: diagenetic segregation, distal turbidites, current effects, surface productivity variations, and changes in influx of clay. Their extensive discussion is summarized here, with some additional observations made at Site 603:

Diagenesis during burial compaction, carbonate dissolution and reprecipitation, and other lithification processes would intensify the differences between clay-rich and clay-poor bands ${ }^{12}$; however, it is very doubtful that diagenesis alone could produce parallel submillimeter laminations from a homogeneous marl-there must have been primary depositional variations on this scale.

A model of dark laminae formation in basin plain deposits favored by Haggerty (this volume) entails both turbidity-current and nepheloid transport and deposition. The lamination and elongate "microflasers" were produced by weak, but active, bottom currents and later enhanced by compaction. Darker laminae and increase in clay content in laminated intervals are interpreted as resulting from periodic influx of clay and terrigenous organic matter from landward turbidity currents that in-

\footnotetext{
12 The "microflaser" structure of many of these laminae suggest that diagenesis may be the main mechanism enhancing the alternation of light and dark laminae.
} 
jected fine-grained materials into the nepheloid layer. The increased suspension of lutite in the nepheloid layer induced slow downslope drift that carried sediment over large areas to settle out onto the basin plain. Haggerty notes that an occurrence of shell boring within a laminated interval $(603 \mathrm{~B}-78-3,65-66 \mathrm{~cm})$ indicates a dysaerobic environment. Circumstantial evidence for the origin of dark laminae by turbidites and nepheloid transport is provided by the association of Lower Cretaceous laminated intervals with the abundance of terrigenous turbidites at most Atlantic DSDP sites. Haggerty, following the facies models of Mutti and Ricci Lucchi (1972), considers that turbidite facies related to basin plain deposits grade uphole into submarine fan deposits in upper Valanginian through Barremian strata. Other examples of laminated deep-sea sediments produced by finegrained turbidites or turbid layer transport downslope are the sediments around Great Meteor Seamount (where coccolith-rich but extremely organic-carbon-poor, reworked carbonate produced hostile conditions for benthic fauna (von Stackelberg et al., 1979) and the sediments of the Santa Barbara Basin of California.

Some observations do not support a hypothesis that laminations at Site 603 resulted solely from the input of clay-rich turbidites into a carbonate host sediment: (1) the dark laminations display no grading of the silt, organic matter, or radiolarian fractions (however, thin distal turbites are commonly not graded; Walker, 1967); (2) the laminations lack sharp contacts; (3) the occurrence and frequency of dark laminae are unrelated to the occurrence and frequency of either claystone or siltstone turbidite beds (e.g., compare Table 4, later, and Fig. 2); and (4) the geochemistry of the inorganic fraction is distinctly different from that of the interbedded claystone turbidites within the laminated intervals (Dean and Arthur, this volume).

Reworking of pelagic sediment by currents ("contourites") is the model proposed by Dean and Arthur (this volume), based on several observations: (1) "the laminations are not very fine as might be expected for deposition under anoxic bottom waters" (although whether anoxic bottom conditions are characterized by a specific range of thickness and frequency of laminae is moot); (2) the variations in thickness of the Blake-Bahama Formation on seismic reflection profiles along the North American continental margin can be attributed to possible contour-current-induced structures (Tucholke and Mountain, 1979); (3) in the laminated intervals, organic matter, of "normal" marine and reworked terrigenous origin, is both more highly concentrated and better preserved; the laminated sediment may have been deposited more rapidly than the bioturbated sediment, perhaps by currents; and (4) the abundances of turbidites indicate that turbidity-current deposition was an important process.

Observations contrary to this model of current-produced lamination are: (1) Cotillon and Rio (1984) identified "first-order" laminae of possible annual cyclicity in SEM observations of laminated marly limestone; (2) the vast majority of laminations are regular and parallel, without grading, ripples, or other sedimentary structures characteristic of contour-current deposits (Lovell and Stow, 1981; see discussion of contour-current deposits in the Site 603 chapter, this volume); (3) variations in the thickness of the Blake-Bahama Formation near the continental margin can be attributed to the presence of turbidites and submarine fans and not to contour currents (Sarti and von Rad, this volume); (4) laminated intervals are characteristic of every DSDP site in the Blake-Bahama Formation and other Lower Cretaceous limestone from the Gulf of Mexico to the eastern North Atlantic, so localized current effects are probably not involved; and (5) the lack of bioturbation, especially if coinciding with high organic-carbon values, is usually, but not necessarily correctly, considered to be characteristic of quiet, stagnant, bottom water rather than active bottom currents (the rare occurrences of Chondrites burrows in laminated intervals are evidence of very low oxygen levels (anoxia) immediately below a surficial oxidized zone (Bromley and Ekdale, 1984).

Some laminations may have been created by local longterm oscillations of a slow nepheloid drift which led to minor variations in the ratio of nannofossils to clay; these differences could then have been enhanced during diagenesis.

The last class of models invokes multiyear (10-yr. periodicity) oscillations in the net influx of terrigenous material (from fluvial, eolian, and storm mechanisms) and in surface productivity (nannoplankton and marine organic matter). All of these models ultimately invoke a quasiperiodic climatic and oceanographic cause. There are several local and regional natural phenomena with irregular cyclicities on the scale of 5-20 yr., such as "red tide" algal blooms, El Niño-type oceanic disturbances, food-chain population fluctuations (and related production of pellets), average rainfall and mean temperature variations, sun spots, frequency and intensities of summer droughts and winter storms, etc.; most of these could result in subtle fluctuations in the ratio of clay to carbonate being deposited over the years on the ocean bottom, but all of them are nearly impossible to demonstrate unambiguously from the sedimentary record alone. Robertson and Bliefnick (1983) consider that the laminations are best explained by long-period pulses in net surface productivity that resulted from a patchy and variable distribution of nutrients and upwelling at the surface. This in turn may have been caused by irregularities in the location and velocity of southwest-flowing gyres within strong westward surface currents of an open Tethys-Atlantic-Pacific seaway during the Early Cretaceous (Fig. 15). It is difficult to envision quasicyclic algal blooms affecting most of the western North Atlantic (the fine laminations occur in similar, coeval, Lower Cretaceous cyclic carbonates from the Iberian margin to the Gulf of Mexico), but the eastern equatorial Pacific El Niño oceanic disturbance of 1984 had global effects on climate and oceanic productivity; perhaps similar phenomena had a major impact on the North Atlantic, which connected directly into the equatorial Pacific during the Early Cretaceous.

\section{Origin of Cycles}

Why is the Blake-Bahama Formation characterized by alternations of laminated marly limestone and bio- 


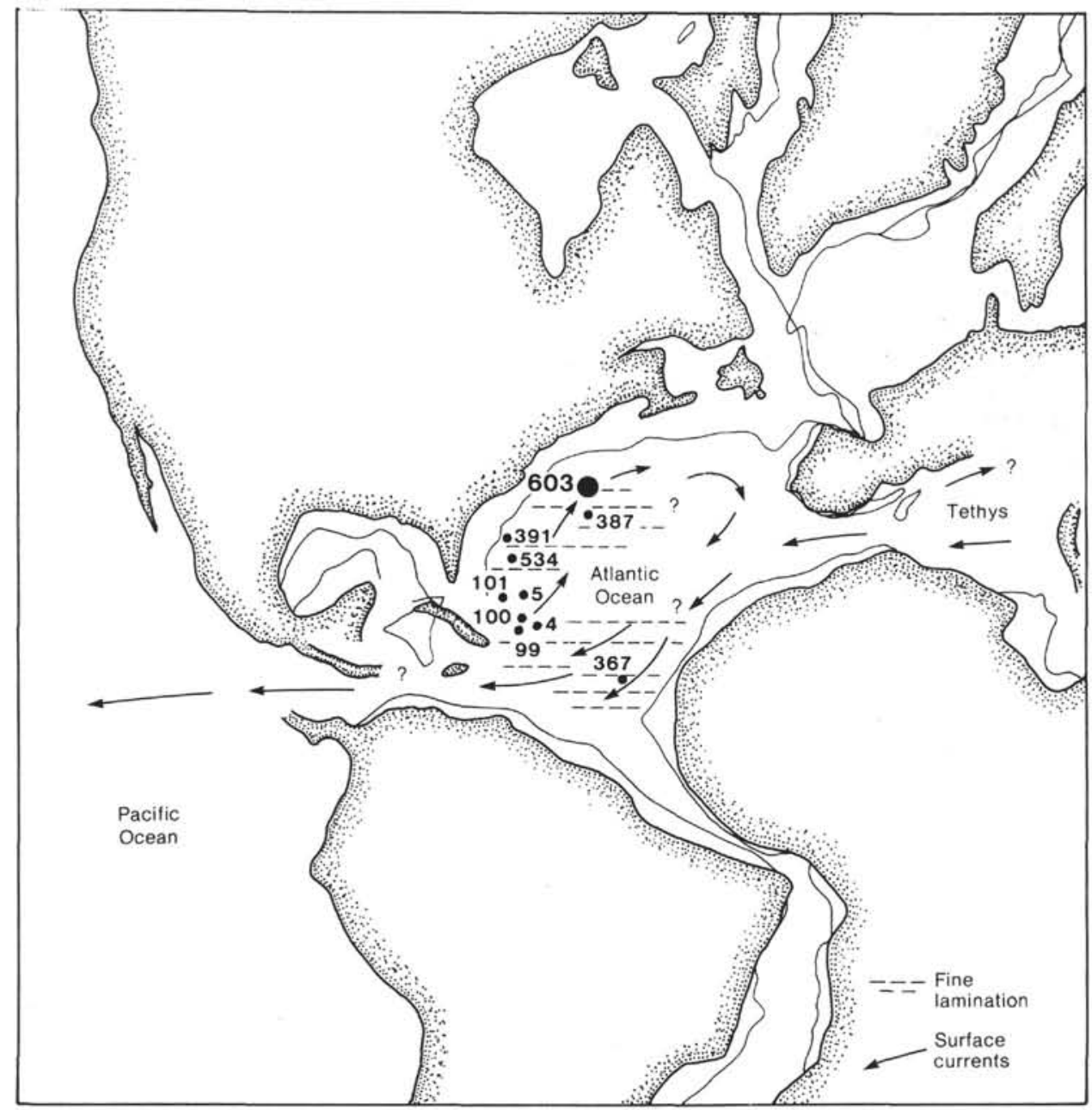

Figure 15. Paleoceanographic setting of Site 603 during the Early Cretaceous, with a possible paleocirculation pattern. DSDP sites with alternations of laminated and bioturbated sediments typical of BlakeBahama Formation are shown. Modified from Robertson and Bliefnick, 1983.

turbated limestone? Every study of this facies on other DSDP legs has concluded that the ultimate driving force is climatic oscillations on a global scale; but how a climatic change actually causes the lithologic alternations is debated.

Estimates of the frequency of major alternations between laminated and bioturbated limestone at Site 603 range from about 25,000 to 40,000 yr. per cycle. ${ }^{13}$ This frequency is similar to estimates obtained by other studies of carbonate cycles in the Early Cretaceous. In addition, there are minor variations in bulk clay and organic content on the scale of 10 to $20 \mathrm{~cm}$, which would have an average frequency of about 7000 to 15,000 yr. Cotillon and Rio (1984), in an extensive study of these carbonate cycles in the Gulf of Mexico and central Atlantic, observed that distinguishing major versus minor cycles can be difficult and is dependent upon sedimentation rate and the subjective judgment of the observer; consequently, it is not feasible to determine frequencies of the component cycles.

\footnotetext{
${ }^{13}$ This is computed from an average of 2 to 3 cycles $/ \mathrm{m}$ pelagic sediment; $200 \mathrm{~m}$ of the pelagic sediment component within the Blake-Bahama Formation at Site 603 spans the latest Berriasian through Barrenian, or about 15 m.y., assuming no hiatuses or condensation.
}

The main differences between the laminated and the bioturbated intervals at Site 603 , constraining models for these cycles, are: (1) laminated intervals contain 8 times more organic carbon than the bioturbated intervals $(1.3 \%$ vs. $0.16 \%)$; (2) laminated intervals have an average of $28 \%$ insoluble residue (mainly clay with minor mica and quartz), the bioturbated an average of $20 \%$; (3) the organic carbon is mainly terrigenous, with an additional marine-derived contribution in the more organic-matter-rich, laminated intervals; (4) turbidite beds are closer-spaced, suggesting that they are more frequent, in the laminated intervals than the bioturbated; (5) calcified radiolarians are more abundant in the bioturbated limestone, although this may be partially an artifact of preservation during early diagenesis; (6) there is a much higher ratio of nannoconids to coccoliths in bioturbated relative to laminated intervals; (7) fish debris, Inoceramus fragments, ammonite aptychi, and foraminifers are more abundant in the laminated intervals; and (8) carbonates in the laminated intervals are enriched in ${ }^{13} \mathrm{C}$ and ${ }^{18} \mathrm{O}$ with respect to those in the bioturbated.

The earliest models for carbonate cycles in the Cretaceous were proposed by Gilbert (1895), and research into the origin and the spectral analysis of sedimentary cy- 
cles has intensified during the past decade as a result of the correlation of the frequencies of cycles to astronomically induced climatic changes. Recent compilations of cyclic climate and sedimentation studies are in Einsele and Seilacher (1982) and Berger et al. (1984) A few of the recent models to explain the origin of rhythmic limestone/marl alternations are summarized in Table 3. Some of the variables incorporated by various models include bottom-water oxygenation, terrigenous clastic input, terrigenous organic material input, carbonate productivity, carbonate dissolution, and diagenetic enhancement. Several of these models were developed to explain Lower Cretaceous carbonate cycles in marine basins on the continents (e.g., western interior of United States and Vocontian Trough of southeastern France) and are not necessarily applicable to the deep sea. Similarly, the following scenario, in which changes in ocean circulation and in terrestrial runoff were simultaneous but independent responses to a common climatic driving factor, applies mainly to Site 603 .

The apparently higher frequency of interbedded, terrigenous clastic turbidites in the laminated intervals relative to the bioturbated intervals suggests either that the sedimentation rate was slower in the laminated intervals (i.e., the absolute frequency of turbidites into the basin was fairly constant over several cycles) or that the supply of terrigenous clastics was increased during the laminated episodes. Our favored model is that both effects were acting together-the sedimentation rate of carbonate was less owing to a reduction in the surface productivity of calcareous nannoplankton, and the terrigenous input, in the form of increased clay and silt and of plant debris, was slightly higher (perhaps caused by a more humid continental climate). A relatively slower sedimentation rate during the laminated intervals is indicated by the higher abundance (with respect to carbonate content) of fish debris, fine-grained clastics, and macrofossils. The circulation of the ocean (upwelling activity, bottom currents, etc.) was less active at Site 603 during the periods of laminated sedimentation. The sluggish circulation was responsible for a slight decrease in surface productivity (especially apparent in the reduced abundance of radiolarians, but also recorded as a decrease in nannofossil production and possibly as a change in the nannofossil assemblages) and for a reduction in the oxygen content of the bottom waters. The higher rate of supply of terrigenous organic matter contributed to a further reduction in the bottom-water oxygen levels and to the establishment of an anaerobic environment within the upper sediment column. The higher organic carbon content resulted in more acidic interstitial waters, which would in turn increase the dissolution of carbonate, thereby enriching the sediment in the insoluble components. The data of Dean and Arthur (this volume) suggest that as the terrigenous organic carbon content approaches $1 \%$, then marine-derived carbon is also preserved in the sediment. At low levels of dissolved oxygen in the interstitial and near-bottom waters, conditions become inhospitable to burrowing infauna, and laminated structures are preserved. The lack of reworking and mixing of the sediment by bioturbation would further aid in the preservation of organic matter.
When ocean circulation began to increase and simultaneously the input of terrigenous clastics and organic carbon decreased, then the oxygen level of the bottom water rose to levels sufficient for an active infauna, and an interval of bioturbated limestone was initiated.

If bottom-water oxygenation did not rise to levels adequate for active bottom infauna communities during the periods of higher surface productivity, the higher carbonate influx and simultaneous reduced input of terrigenous clastics and organic material would result in a lighter-colored laminated interval adjacent to darker-colored laminated ones. Similarly, if the bottom waters did not become anaerobic during the periods of increased terrigenous input, then darker-colored bioturbated intervals would be formed adjacent to light-colored ones.

Why the ocean circulation would periodically vary and how this would be related to more global change is another tempting level of speculation, but beyond the scope of this chapter. Some possible astronomic and climatic mechanisms governing the oceanic cycles are proposed by models included in Table 3 . The foregoing scenario incorporated elements of previous models; other scenarios may also satisfy the constraints.

\section{SEDIMENTATION HISTORY}

\section{Biostratigraphy}

The standard zonation for the Early Cretaceous is established in ammonite- and foraminifer-rich sections in southeastern France. The western Atlantic Lower Cretaceous sediments have only rare ammonites, and therefore the biostratigraphy is based mainly on nannofossils and dinoflagellates, with limited control from foraminifers and calpionellids. The dinoflagellate zonation for the Atlantic is calibrated to the standard Early Cretaceous sections in France and is based primarily on lowest occurrences of index species (however, the placement of some stage boundaries relies on the highest occurrences of species). The nannofossil zonation for the Early Cretaceous in the Atlantic is still undergoing refinement and calibration to standard stages. Further details of the biostratigraphic zonations for the Early Cretaceous are found in Moullade; Ogg; Habib and Drugg; and Covington and Wise (all this volume). The dinoflagellate zonation and corresponding assignment of stage boundaries will be used in this presentation of the sedimentation history.

\section{Pelagic Facies Subunits and Regional Correlations}

The alternations or cycles between the dark-colored laminated and light-colored bioturbated limestone change character from core to core. In some portions of the sedimentary column, the "cycles" are apparent only as changes in the degree of bioturbation or in the darkness of the sediment, as discussed earlier; indeed, in many cores, the pelagic sediment displays nearly continuous bioturbated or laminated structures.

The proportions of laminated (light- and dark-colored), bioturbated, and intermediate structures and the type and clarity of rhythmic alternations between the structures were tabulated for each core of Hole 603B. A similar compilation was made for the upper Berriasian 
Table 3. Models for bioturbated limestone/laminated marl alternations (cycles) of Cretaceous age.

\begin{tabular}{|c|c|c|}
\hline $\begin{array}{l}\text { Reference, age, } \\
\text { location studied }\end{array}$ & $\begin{array}{l}\text { Primary } \\
\text { variables }\end{array}$ & $\begin{array}{l}\text { Sequence of cause and effect generating } \\
\text { laminated marl component of cycle }\end{array}$ \\
\hline $\begin{array}{l}\text { Gilbert (1895), Upper } \\
\text { Cret., w. interior U.S. } \\
\text { (3 models) }\end{array}$ & $\begin{array}{l}\text { 2. Current pattern } \\
\text { 3. Terrigenous clastics }\end{array}$ & $\begin{array}{l}\text { Growing glaciers-sea level regression-clay-rich } \\
\text { sedimentation } \\
\text { Global wind paterns change-currents bring in } \\
\text { mud from western shores. } \\
\text { Arid climate-reduced plant cover-higher ratio } \\
\text { of detrital/dissolved material in runoff. }\end{array}$ \\
\hline $\begin{array}{l}\text { Fischer (1980), } \\
\text { Upper Cret., w. } \\
\text { interior U.S. }\end{array}$ & $\begin{array}{l}\text { Bottom-water } \\
\text { oxygenation }\end{array}$ & $\begin{array}{l}\text { Restricted circulation, humid climate-abundant } \\
\text { fresh water influx, or reduction or shifting of } \\
\text { winds and currents-stratified water col- } \\
\text { umn-dysaerobic to anaerobic bottom wa- } \\
\text { ter-laminated sedimentation. }\end{array}$ \\
\hline $\begin{array}{l}\text { Barron et al. (1985), } \\
\text { Arthur et al. (1984), } \\
\text { and Pratt (1982), Upper } \\
\text { Cret., w. interior U.S. }\end{array}$ & $\begin{array}{l}\text { Terrigenous clastics, } \\
\text { bottom-water } \\
\text { oxygenation }\end{array}$ & $\begin{array}{l}\text { Summer perihelion and greater axial tilt-greater } \\
\text { seasonal insolation cycle-increased storms } \\
\text { and precipitation-greater rainfall and run- } \\
\text { off-lower surface salinity and greater terrig- } \\
\text { enous clastic input-stratification of water } \\
\text { column and maybe higher net sedimentation. }\end{array}$ \\
\hline $\begin{array}{l}\text { Barron et al. (1985), } \\
\text { unspecified ocean basins }\end{array}$ & $\begin{array}{l}\text { Bottom-water } \\
\text { oxygenation }\end{array}$ & $\begin{array}{l}\text { Increased net evaporation in semienclosed ba- } \\
\text { sins-warm saline outflow-modulates } \\
\text { global deep water formation, stratification, } \\
\text { and turnover-change of balance of surface } \\
\text { organic matter production to deep water } \\
\text { masses (also changes in zonal wind patterns } \\
\text { and intensities - changes in local and region- } \\
\text { al upwelling and nutirent supply). }\end{array}$ \\
\hline $\begin{array}{l}\text { Arthur (1979), Upper } \\
\text { Cret., Italy (Gubbio) }\end{array}$ & Dissolution & $\begin{array}{l}\text { Lysocline rises with respect to seafloor-rate of } \\
\text { carbonate dissolution increases-more clay- } \\
\text { rich residual sediments. }\end{array}$ \\
\hline $\begin{array}{l}\text { Dean et al. (1978), } \\
\text { lower Tertiary, DSDP } \\
\text { Site } 366\end{array}$ & Dissolution & Same model as Arthur (1979) above. \\
\hline $\begin{array}{l}\text { Arthur et al. (1984), } \\
\text { unspecified ocean basins }\end{array}$ & $\begin{array}{l}\text { Dissolution } \\
\text { bottom-water } \\
\text { oxygenation }\end{array}$ & $\begin{array}{l}\text { Solar insolation variation-changing pattern of } \\
\text { evaporation, precipitation-changing surface } \\
\text { salinity, stratification. Changing wind stress } \\
\text { patterns-changes of surface overturn, nutri- } \\
\text { ent supply, and productivity; changes in deep } \\
\text { water turnover, oxygen content, and carbon- } \\
\text { ate dissolution. }\end{array}$ \\
\hline $\begin{array}{l}\text { de Boer (1983), de } \\
\text { Boer and Wonders (1984), } \\
\text { mid-Cret., Italy }\end{array}$ & $\begin{array}{l}\text { Carbonate } \\
\text { productivity }\end{array}$ & $\begin{array}{l}\text { Solar insolation shifts caloric equator north- } \\
\text { ward-less seasonal contrast at low latitudes } \\
\text { in N. Hemisphere, equatorial upwelling zone } \\
\text { and subtropical convergence zones shift } \\
\text { northward and are reduced in strength-de- } \\
\text { crease of current intensities, relatively poor } \\
\text { circulation-increased stratification, low nu- } \\
\text { trient supply, warm surface waters-lower } \\
\text { productivity and poor replenishment of oxy- } \\
\text { gen to deep water-lower carbonate contri- } \\
\text { bution to sediment, increased preservation of } \\
\text { organic carbon. }\end{array}$ \\
\hline $\begin{array}{l}\text { Roth (1983a), mid-Cret., } \\
\text { Pacific and Atlantic }\end{array}$ & Productivity & $\begin{array}{l}\text { Increased surface productivity (with greater spe- } \\
\text { cies abundance)-oxygen depletion in bot- } \\
\text { tom waters-laminated sedimentation. }\end{array}$ \\
\hline $\begin{array}{l}\text { Einsele (1982), } \\
\text { unspecified ocean basins }\end{array}$ & $\begin{array}{l}\text { Carbonate productivity, } \\
\text { dissolution, } \\
\text { bottom-water } \\
\text { oxygenation }\end{array}$ & $\begin{array}{l}\text { Arid climate-reduced global vegetation cover- } \\
\text { increased detrital and reduction of bicarbon- } \\
\text { ate in runoff; reduced } \mathrm{CO}_{2} \text { and } \mathrm{O}_{2} \text { exchange } \\
\text { to deep waters-decreased carbonate produc- } \\
\text { tion, rise of } \mathrm{CCD} \text {, decreased bottom-water } \\
\text { oxygenation-increased carbonate dissolu- } \\
\text { tion, no infauna-laminated marl. }\end{array}$ \\
\hline $\begin{array}{l}\text { Cotillon and Rio (1984), } \\
\text { Lower Cret., Gulf of } \\
\text { Mexico (DSDP Leg 77) }\end{array}$ & $\begin{array}{l}\text { Productivity, } \\
\text { terrigenous clastics }\end{array}$ & $\begin{array}{l}\text { Warmer, drier climate: } \\
\text { 1. Warmer surface waters, less active circula- } \\
\text { tion-stratification, less nutrient upwelling. } \\
\text { deep water stagnation-lower productivity } \\
\text { but more diversity of planktonic life, preser- } \\
\text { vation of organic carbon, no infauna-slow- } \\
\text { er net sedimentation. } \\
\text { 2. Less land plant cover-enhanced continental } \\
\text { erosion-influx of more terrigenous clastics. }\end{array}$ \\
\hline $\begin{array}{l}\text { Robertson and Bliefnick } \\
\text { (1983), Lower Cret., } \\
\text { Site } 534 \text { (Atlantic) }\end{array}$ & $\begin{array}{l}\text { Terrigenous organic } \\
\text { matter, diagenetic } \\
\text { enhancement }\end{array}$ & $\begin{array}{l}\text { Humid-prolific vegetation-increased terige- } \\
\text { nous organic debris to seafloor-oxygen de- } \\
\text { pletion of interstitial waters-no infauna, } \\
\text { preservation of organic carbon. Diagenesis } \\
\text { enhances differences between marl and lime- } \\
\text { stone. (Laminae are caused by pulses in pro- } \\
\text { ductivity resulting from variations in upwell- } \\
\text { ing.) }\end{array}$ \\
\hline $\begin{array}{l}\text { Dean and Arthur (this } \\
\text { volume), Lower Cret., } \\
\text { Site } 603 \text { (Atlantic) }\end{array}$ & Bottom curents & $\begin{array}{l}\text { More active bottom currents-reworking of ter- } \\
\text { rigenous detritus and formation of laminated } \\
\text { structures; perhaps a higher net sedimenta- } \\
\text { tion rate. }\end{array}$ \\
\hline $\begin{array}{l}\text { Haggerty (this volume), } \\
\text { Lower Cret., Site } 603\end{array}$ & $\begin{array}{l}\text { Terrigenous clastics } \\
\text { organic matter }\end{array}$ & $\begin{array}{l}\text { Enhanced nepheloid drift and disposition create } \\
\text { dark laminae; more organic matter and more } \\
\text { lutite-hostile environment for infauna. }\end{array}$ \\
\hline
\end{tabular}


through Aptian sediments in Hole 534A, located in the Blake-Bahama Basin (Fig. 1). There are several distinct changes in facies of the Lower Cretaceous pelagic limestone which make it possible to subdivide the pelagic sediment column at each site into four main lithostratigraphic units with several subunits (Table 4). This examination excluded turbidite beds of all types, because such beds are probably local in extent; although the intervals of abundant turbidite input (e.g., in the upper Barremian) may be coeval over a large region.

These lithologic subunits of the pelagic sediments could be correlated between Holes 603B and 534A. The correlations use the dinoflagellate biostratigraphy for age control and were refined by comparing core photographs and by examining cores from the two sites at the Lamont-Doherty East Coast DSDP Repository. As informal notation, the four main facies units are labeled A$\mathrm{D}$ and their subunits are numbered upsection (Table 4). The results are consistent with the magnetostratigraphy (Ogg, this volume), indicating that the facies changes are relatively coeval between the two sites. These two sites have the most complete recovery of Lower Cretaceous sediments in the western North Atlantic, which suggests that the pelagic sediment subunits reflect basinwide changes in oceanic environment and sedimentation.

Another method of subdividing and correlating the Lower Cretaceous pelagic sediment column is to use the frequency, symmetry, and other characteristics of the cycles within the limestone. Cotillon and Rio (1984) used this technique to correlate DSDP Sites 535 (Gulf of Mexico) and 534 to the pelagic sediment stratotypes of the
Lower Cretaceous in the Vocontian Basin of southern France; and extension may even be possible to DSDP sites in the Pacific (Cotillon, 1984). The facies subdivisions used in this paper are based upon general lithologic characteristics, but these also appear to be present in the Vocontian Basin sections (e.g., Cotillon, 1971; Cotillon et al., 1980; Ogg, unpubl. data). Combining the two approaches - the general facies subdivision and the detailed cycle characteristics - may make possible highresolution basinwide and intrabasinal correlations for Lower Cretaceous pelagic sediments and may also make possible correlation to detailed biostratigraphic zonations and magnetostratigraphy.

\section{Berriasian}

The drilling at Site 603 was terminated in uppermost Berriasian sediments; the lowermost Blake-Bahama Formation was not penetrated. From other DSDP sites, it is known that the light gray limestone of the Blake-Bahama Formation overlies reddish brown marl and marly limestone ("Cat Gap Formation" of Jansa et al., 1979). The change upward from red marl to white limestone results from an increase in the sedimentation rate of carbonate during the late Tithonian. The increased carbonate/clay ratio correlates with an increased ratio of buried organic carbon to Fe; the latter ratio increases the postburial reduction of the iron, which results in the gradual loss of red coloration (Ogg et al., 1983). The lower Berriasian is characterized by white, radiolarianrich, nannofossil limestone with clay seams. From a comparison of the ages and facies of Site 603 to the complete record at Site 534 in the Blake-Bahama Basin, it

Table 4. Lithologic units of pelagic sediments, Early Cretaceous, Sites 603 and 534.

\begin{tabular}{|c|c|c|c|c|c|}
\hline \multirow{2}{*}{\multicolumn{2}{|c|}{$\begin{array}{l}\text { Pelagic } \\
\text { subunit }\end{array}$}} & \multirow[b]{2}{*}{ Description } & \multicolumn{2}{|c|}{ Interval (cores) } & \multirow[b]{2}{*}{ Age } \\
\hline & & & Hole 603B & Hole $534 \mathrm{~A}$ & \\
\hline A & B dor & $\begin{array}{l}\text { minant, with } \\
\mathrm{B} / \mathrm{BL} \text { alternations }\end{array}$ & $82-$ mid 80 & $\begin{array}{l}\text { Uncertain if present, } \\
\text { Maybe } 83-84\end{array}$ & latest Berr. \\
\hline \multirow[t]{4}{*}{ B } & Prima & arily L: & & & \\
\hline & B1 & $\mathrm{L}$ dominant & Mid 80-lower 78 & $\begin{array}{l}\text { Uppermost } 82- \\
\text { mid } 78\end{array}$ & earliest Val. \\
\hline & B2 & $\begin{array}{l}\mathrm{B} / \mathrm{L} \text { cycles } \\
\text { (narrow interval) }\end{array}$ & Lower 78-top 77 & Mid $78-$ mid 77 & early Val. \\
\hline & B3 & L dominant & Base 76 -lower 74 & Mid 77-mid 74 & late Val. \\
\hline \multirow[t]{3}{*}{ C } & Cycle & & & & \\
\hline & $\mathrm{Cl}$ & $\begin{array}{l}\text { B/L cycles, } \\
\text { well-developed }\end{array}$ & Lower 74-upper 62 & Mid 74-mid 64 & $\begin{array}{l}\text { latest Val.- } \\
\text { e. Haut. }\end{array}$ \\
\hline & $\mathrm{C} 2$ & $\begin{array}{l}\mathrm{BL} / \mathrm{L} \text { cycles, } \\
\text { less well-developed }\end{array}$ & Upper 62-top 58 & $\begin{array}{l}\text { Mid } 64-58 \\
\qquad[\text { Core } 57=\text { gap] }\end{array}$ & $\begin{array}{l}\text { late Haut., maybe } \\
\text { basal Barrem. }\end{array}$ \\
\hline \multirow[t]{6}{*}{ D } & L. do & ominant: & & & \\
\hline & D1 & L & $57-55$ & $57 ?, 56-54$ & e. Barrem. \\
\hline & D2 & $\begin{array}{l}\text { BL-B-L to highest } \\
\text { well-developed B }\end{array}$ & $54-51-2$ & $53-51 ?$ & $\begin{array}{l}\text { mid and late } \\
\text { Barrem. }\end{array}$ \\
\hline & D3 & $\begin{array}{l}\text { L (cycles of } \\
\text { light/dark) }\end{array}$ & $51-2-45 ?$ & $50-48$ & $\begin{array}{l}\text { 1. Barrem., } \\
\text { basal Apt. }\end{array}$ \\
\hline & D4 & $\begin{array}{l}\mathrm{L} / \mathrm{BL} \text { to highest } \\
\mathrm{B} \text { or } \mathrm{BL} \text { bed }\end{array}$ & ? Missing ? & $\begin{array}{l}\text { 47-45-3; } \\
\quad \text { (minor BL at } 45-1 \text { ) }\end{array}$ & Aptian \\
\hline & D5 & Dark L & Basal 44-44-1 & Upper 45 -lower 44 & Aptian \\
\hline
\end{tabular}

Note: Subunits are distinguished according to the dominant structures: $\mathrm{B}=$ bioturbated light-colored limestone; $\mathrm{L}$ $=$ laminated darker-colored marly limestone; $\mathrm{BL}=$ intermediate (laminated with minor bioturbation); $\mathrm{B} / \mathrm{L}=$ alternations of $\mathrm{B}$ and $\mathrm{L} ; \mathrm{L} / \mathrm{BL}=$ alternating $\mathrm{L}$ and $\mathrm{BL}$, etc. Ages are according to the dinoflagellate biostratigraphy of the sites. 
appears that the drilling at Site 603 was terminated about 10 to $30 \mathrm{~m}$ above the white limestone member of the Blake-Bahama Formation.

In the upper Berriasian, there is a gradual increase in the clay and organic-carbon content of the pelagic limestone of the Blake-Bahama Formation and a corresponding gradual change from homogeneous, bioturbated white limestone to alternations (cycles) of laminated gray and bioturbated light gray limestone. The upper Berriasian (Core 603 B-82 to mid-Core 80 ) consists predominantly of alternating completely and partially bioturbated light gray limestone (lithologic pelagic unit "A" of Table 4).

It is not certain that this uppermost Berriasian facies is present at Site 534; instead, an apparent sudden change of facies is present. Other lines of evidence suggest a hiatus at the Berriasian/Valanginian boundary: a prominent regional reflector C' (Gradstein et al., 1983; Sheridan et al., 1983) and the presence of several biostratigraphic datums (Roth, 1983b; Habib and Drugg, 1983). A major hiatus and unconformity of basal Valanginian age occurs throughout the North Atlantic and has been correlated with a major episode of rapid sea level change (Vail et al., 1980; Vail and Todd, 1980; Emery and Uchupi, 1984). This regional hiatus was not identified at Site 603 .

\section{Valanginian}

The Valanginian portion of the Blake-Bahama Formation is dominated by laminated marly limestone (middle of Core $603 \mathrm{~B}-80$ to lower Core 74 ; lithologic pelagic unit B of Table 4). Intervals of bioturbated limestone are abundant only in the upper part of the lower Valanginian (Cores 77 and 78; subunit "B2").

The Valanginian sediments have the most abundant clay (averaging about $60 \% \mathrm{CaCO}_{3}$ ) and organic carbon (averaging 1.4-1.5\%) of the Lower Cretaceous pelagic sediments. Haggerty (this volume) suggests that the laminated marly limestone is related to an increase in terrigenous clastic influx from the shelf, which led to the enhancement of nepheloid transport and deposition which formed the dark laminations. The more proximal portions of the terrigenous turbidites did not reach the site until the late Valanginian-early Hauterivian, as the outbuilding of the fans progressed. The Valanginian through Barremian is marked on many of the margins of the Atlantic by the deposition of terrigenous clastics or "Wealden facies" (Emery and Uchupi, 1984); the pelagic sedimentary sections of the Valanginian in southern France are also marked by a high influx of clay and silt (Cotillon et al., 1980).

\section{Hauterivian}

The entire Hauterivian portion of the Lower Cretaceous pelagic sediments is characterized by cycles of bioturbated limestone and laminated marly limestone (uppermost Valanginian of Core 603B-74 to the uppermost Hauterivian or basal Barremian in Core 58; lithologic pelagic unit " $C$ " of Table 4). The bioturbated and laminated structures occur in nearly equal proportions. In the upper Hauterivian, the degree of bioturbation appears to be less, although the cycles are still visible (upper part of Core 603B-62 through Core 58; subunit “C2").
The lowermost Hauterivian at Site 603 (Cores 603B70 to -73 ) contains abundant terrigenous clastic turbidites, which constitute as much as $65 \%$ of the cores. These turbidites are primarily black silty claystone, in contrast to the coarse clastic (sandy siltstone) turbidites of the uppermost Hauterivian and Barremian. This turbidite episode at Site 603 of the lowermost Hauterivian is absent in the type sections of the Blake-Bahama Formation (Sites 391 and 534).

\section{Barremian}

The Barremian at Site 603 (Core 603B-57 through 45 ) is dominated by clastic turbidites, interpreted to be from an active submarine fan (Sarti and von Rad, this volume). The peak of terrigenous clastic input is represented by thick sand beds in the uppermost Barremian and basal Aptian (Cores 48 through 45). Clastic turbidites are also characteristic of this portion of the BlakeBahama Formation at Site 534 in the south, although these contain redeposited shallow-water carbonate debris (Robertson and Bliefnick, 1983).

The pelagic sediments are predominantly laminated limestone with intervals of poorly developed bioturbated structures. The highest well-developed bioturbated intervals are in Section 603B-51-2; the pelagic sediments above this level consist of alternating light- and dark-colored laminated limestone (pelagic subunit "D3").

In Hole 534A, there is another interval with partially bioturbated beds (pelagic subunit "D4" of Table 4) with a possible age of early Aptian. This pelagic facies subunit was not identified at Site 603. A hiatus or condensation of the pelagic sediments is also indicated by the paleontology and magnetostratigraphy of the upper Barremian and lower Aptian (Ogg, this volume). Sarti and von Rad (this volume) suggest that pelagic sediment erosion or condensation may be associated with the influx of the massive sand beds of Cores $603 \mathrm{~B}-48$ to -45 . The combination of hiatuses in sedimentation and of the presence of major lithologic changes and corresponding changes in physical properties within this interval are probably the cause of seismic Reflector $\beta$ in this region of the western Atlantic (see the seismic stratigraphy section, Site 603 chapter; Biart; Wise and van Hinte; all this volume). Unconformities of earliest Aptian age occur elsewhere in the North Atlantic and have been correlated with a major eustatic change (Vail et al., 1980; Vail and Todd, 1980; Emery and Uchupi, 1984).

\section{Aptian and Top of Lower Cretaceous Limestone}

Only Core $603 \mathrm{~B}-44$ is of definite Aptian age, although some underlying cores may also be Aptian. The uppermost occurrence of laminated marly limestone is at 603B44-1, $32 \mathrm{~cm}$. Dark, laminated limestone constitutes only about $10 \%$ of the sediment; the remainder is claystone turbidites.

The contact of Lithologic Unit V ("Blake-Bahama Formation") with the overlying black, organic-matterrich and carbonate-free claystone of Lithologic Unit IV ("Hatteras Formation") is at the top of the highest layer of nannofossil-rich marly limestone; at Site 603, this sharp change in facies is probably a hiatus or erosional con- 
tact. This lithologic unit boundary level is probably not coeval with the top of the Blake-Bahama Formation as defined at other DSDP sites. At Site 534, the boundary between the Blake-Bahama Formation and the Hatteras Formation is "gradational and is taken to be where the sediments become much less calcareous (Core 47), indicating deposition close to the calcite compensation depth" (Robertson and Bliefnick, 1983, pp. 795-796); this criterion is consistent with the placement of the boundary at Site 603 , although the stratigraphy is complicated by hiatuses at Site 603, and slightly less calcareous sediments continue at Site 534 to Core 534A-44. Jansa et al. (1979) defined the top of the Blake-Bahama Formation in its "type section" at Site 391 to be the level "above which limestone is subordinate to dark claystone beds" (which at Site 391 also corresponds to a 37-m gap in recovery!). Examination of the facies and reported ages of this "type section" indicates that this definition of the top of the Blake-Bahama Formation would correspond to the highest bioturbated interval in Section 603B-51-2; this level is slightly below the base of the massive sand beds of the upper Barremian-lower Aptian. Therefore, there is a dilemma in selecting that event from among the several major local and regional lithologic changes that is most significant and most useful for correlating facies (hence, defining a "formation") between sites.

\section{SUMMARY}

Pelagic sedimentation during the Early Cretaceous at Site 603 produced alternations of laminated marly limestone and bioturbated limestone-a facies typical of the "Blake-Bahama Formation" of the western Atlantic. This limestone is a nannofossil micrite, rich in calcified radiolarians, with variable amounts of organic matter, pyritized radiolarian tests, fish debris, and micaceous silt. The laminated marly limestone layers are enriched in organic matter compared to bioturbated intervals. The organic carbon is predominantly terrestrial plant debris; where the organic-carbon content is in excess of $1 \%$, there is also a significant marine-derived component. Laminations can result either from bands alternately enriched and depleted in opaque material and clay, or from bands of elongate lenses (microflasers) of micrite, which could be plastically deformed pellets or diagenetic features.

The alternating intervals of laminated and bioturbated structures may have resulted from a combination of changes in surface productivity, in the influx of terrigenous organic matter, and in the intensity of bottom circulation, which led to episodic oxygen depletion in the bottom water and sediments.

Variations in the relative proportions of laminated clayrich and bioturbated lime-rich limestone and in the development of cycles between these structures make it possible to subdivide the Lower Cretaceous pelagic facies into several subunits which appear to be regional in extent. Bioturbated limestone is dominant in the Berriasian, laminated marly limestone in the Valanginian and Barremian-lower Aptian, and well-developed alternations between these end members in the Hauterivian. The Hauterivian to lower Aptian sediments contain abundant, ter- rigenous clastic turbidites associated with a submarine fan complex. These changes in the general characteristics of the pelagic sediment component of the Blake-Bahama Formation at Site 603 are synchronous with those in the Blake-Bahama Basin (Sites 534 and 391) to the south. The cessation of carbonate sedimentation in the early Aptian was probably the result of a regional shoaling of the carbonate compensation depth.

\section{ACKNOWLEDGMENTS}

We thank the Deep Sea Drilling Project for allowing our participation on Leg 93 and supporting postcruise visits to the core repository at Lamont-Doherty Geological Observatory. Many of the observations and interpretations presented here are from our shipboard colleagues. This synthesis benefited immensely from preprints of papers by W. Dean and M. Arthur (geochemistry, isotopes), D. Habib and W. Drugg (palynology), P. Meyers (organic geochemistry), and M. Baltuck (isotopes, diagenesis). We thank L. Jansa and P. Cotillon for useful discussions on various aspects of sedimentation during the Early Cretaceous, and E. L. Winterer, R. E. Sheridan, and T. Bralower for reviewing an earlier manuscript. The compilation of this synthesis was partially supported by EAR82-06263 and INT 82-13069 (Early Cretaceous cyclic sediments) and by OCE83-07771 (Mesozoic paleoceanography). M. Sarti benefited from funding from Consiglio Nazionale delle Ricerche, Rome.

\section{REFERENCES}

Arthur, M. A., 1979. Sedimentologic and geochemical studies of Cretaceous and Paleogene pelagic sedimentary rocks: the Gubbio sequence [Ph.D. dissert.]. Princeton University.

Arthur, M. A., Dean W. E., Bottjer, D., and Scholle, P. A., 1984. Rhythmic bedding in Mesozoic-Cenozoic pelagic carbonate sequences: the primary and diagenetic origin of Milankovitch-like cycles. In Berger, A. L., Imbrie, J., Hays, J., Kukla, G., and Saltzman, E. S. (Eds.), Milankovitch and Climate (Pt. 1): Dordrecht (D. Reidel Publ. Co.), 191-222.

Arthur, M. A., Dean, W. E., and Claypool, G. E., 1985. Anomalous ${ }^{13} \mathrm{C}$ enrichment in modern marine organic carbon. Nature, 315: 216-218.

Barron, E. J., Arthur, M. A., and Kauffman, E. G., 1985. Cretaceous rhythmic bedding sequences: a plausible link between orbital variations and climate. Earth Planet. Sci. Lett., 72:327-340.

Berger, A. L., Imbrie, J., Hays, J., Kukla, G., and Saltzman, E. S. (Eds.), 1984. Milankovitch and Climate (2 parts): Dordrecht (D. Reidel Publ. Co.).

Bernoulli, D., 1972. North Atlantic and Mediterranean Mesozoic facies: a comparison. In Hollister, C. D., Ewing, J. I., et al., Init. Repts. DSDP, 11: Washington (U.S. Govt. Printing Office), 801871.

Boer, P. L. de, 1983. Aspects of Middle Cretaceous Pelagic Sedimentation in Southern Europe; Production and Storage of Organic Matter, Stable Isotopes, and Astronomical Influences. Utrecht, Instituut voor Aardwetenschappen der Rijksuniversiteit, Geologica Utraiectina, 31 .

Boer, P. L. de, and Wonders, A. A. H., 1984. Astronomically induced rhythymic bedding in Cretaceous pelagic sediments near Moria (Italy). In Berger, A. L., Imbrie, J., Hays, J., Kukla, G., and Saltzman, E. S. (Eds.), Milankovitch and Climate (Pt. 1): Dordrecht (D. Reidel Publ. Co.), 177-190.

Bromley, R. G., and Ekdale, A. A., 1984. Chondrites: a trace fossil indicator of anoxia in sediments. Science, 224:872-874.

Cotillon, P., 1971. Le Crétacé inférieur de l'arc subalpin de Castellane entre l'Asse et le Var. Stratigraphie et sédimentologie. Mem. Bur. Rech. Géol. Min., France, 68.

1984. Tentative world-wide correlation of Early Cretaceous strata by limestone-marl cyclicities in pelagic deposits. Bull. Geol. Soc. Denmark, 33:91-102.

1985. Les variations à différentes échelles du taux d'accumulation sedimentaire dans les séries pélagiques alternantes du Crétacé inférieur, conséquences de phénomènes globaux. Essai d'évaluation. Bull. Soc. Geol. France, Ser. 8, 1:59-68.

Cotillon, P., Ferry, S., Gaillard, C., Jautée, E., Latreille, G., and Rio, M., 1980. Fluctuation des paramètres du milieu marin dans le do- 
maine vocontien (France Sud-Est) au Crétacé inférieur: mise en évidence par l'étude des formations marno-calcaires alternantes. Bull. Soc. Geol. France, Ser. 7, 22:735-744.

Cotillon, P., and Rio, M., 1984. Cyclic sedimentation in the Cretaceous of Deep Sea Drilling Project Sites 535 and 540 (Gulf of Mexico), 534 (Central Atlantic), and in the Vocontian Basin (France). In Buffler, R. T., Schlager, W., et al., Init. Repts. DSDP, 77: Washington (U.S. Govt. Printing Office), 339-376.

Darmedru, C., Cotillon, P., and Rio, M., 1982. Rythmes climatiques et biologiques en milieu marin pélagique. Leurs relations dans les dépôts crétacés alternants du bassin vocontien (Sud-East de la France). Bull. Soc. Geol. France, Ser. 7, 24:627-640

Dean, W. E., Gardner, J. V., Jansa, L. F., Cepek, P., and Seibold, E., 1978. Cyclic sedimentation along the continental margin of northwest Africa. In Lancelot, Y., Seibold, E., et al., Init. Repts. DSDP, 41: Washington (U.S. Govt. Printing Office), 965-989.

Einsele, G., 1982. Limestone-marl cycles (periodites): diagnosis, significance, causes-a review. In Einsele, G., and Seilacher, A. (Ed.), Cyclic and Event Stratification: New York (Springer-Verlag), pp. $8-53$.

Einsele, G., and Seilacher, A. (Eds.), 1982. Cyclic and Event Stratification: New York (Springer-Verlag).

Emery, K. O., and Uchupi, E., 1984. The Geology of the Atlantic Ocean: New York (Springer-Verlag).

Fischer, A. G., 1980. Gilbert-Bedding rhythms and geochronology. In Yochelson, E. L. (Ed.), The Scientific Ideas of G. K. Gilbert. Geol. Soc. Am. Spec. Paper, 183:93-104.

Freeman, T., and Enos, P., 1978. Petrology of Upper Jurassic-Lower Cretaceous limestones, DSDP Site 391. In Benson, W. E., Sheridan, R. E., et al., Init. Repts. DSDP, 44: Washington (U.S. Govt. Printing Office), 463-475.

Gilbert, G. K., 1958. Sedimentary measurement of geologic time. $J$. Geol., 3:121-127.

Gradstein, F. M., Sheridan, R. E., et al., 1983. Site 534: Blake-Bahama Basin. In Gradstein, F. M., Sheridan, R. E., et al., Init. Repts. $D S D P, 76$ : Washington (U.S. Govt. Printing Office), 141-340.

Habib, D., and Drugg, W. S., 1983. Dinoflagellate age of Middle Jurassic-Early Cretaceous sediments in the Blake-Bahama Basin. In Gradstein, F. M., Sheridan, R. E., et al., Init. Repts. DSDP, 76: Washington (U.S. Govt. Printing Office), 623-638.

Jansa, L., Enos, P., Tucholke, B. E., Gradstein, F. M., and Sheridan, R. E., 1979. Mesozoic-Cenozoic sedimentary formations of the North American Basin, western North Atlantic. In Talwani, M., Hay, W., and Ryan, W. B. F. (Eds.), Deep Drilling Results in the Atlantic Ocean: Continental Margins and Paleoenvironment. Am. Geophys. Un., Maurice Ewing Ser., 3:1-57.

Jansa, L., Gardner, J. V., and Dean, W. E., 1978. Mesozoic sequences of the central North Atlantic. In Lancelot, Y., Seibold, E., et al., Init. Repts. DSDP, 41: Washington (U.S. Govt. Printing Office), 991-1031.

Lancelot, Y., Hathaway, J. C., and Hollister, C. D., 1972. Lithology of sediments from the western North Atlantic In Hollister, C. D., Ewing, J. I., et al., Init. Repts. DSDP, 11: Washington (U.S. Govt. Printing Office), 901-949.

Létolle, R., Renard, M., Bourbon, M., and Filly, A., 1978. O ${ }^{18}$ and $\mathrm{C}^{13}$ isotopes in Leg 44 carbonates: a comparison with the Alpine series. In Benson, W. E., Sheridan, R. E., et al., Init. Repts. DSDP, 44: Washington (U.S. Govt. Printing Office), 567-572.

Lovell, J. P. B., and Stow, D. A. V., 1981. Identification of ancient sandy coutourites. Geology, 9:347-349.

Müller, C., Schaaf, A., and Sigal, J., 1983, 1984. Biochronostratigraphie des formations d'âge Crétacé dans les forages du DSDP dans l'Océan Atlantique Nord. Rev. Inst. Franc. Pet., 38:683-708; 39:3-23.

Mutti, E., and Ricci Lucchi, F., 1972. Le torbiditi dell'Appennino Settentrionale: introduzione all'analisi di facies. Mem. Soc. Geol. It., 11:161-199.

Noël, D., 1968. Nature et génèse des alternances de marnes et des calcaires du Barrémien supérieur d'Angles (Fosse vocontienne, Basses-Alpes). C. R. Acad. Sci. Paris, 266:1223-1225.
Ogg, J. G., Robertson, A. H. F., and Jansa, L. F., 1983. Jurassic sedimentation history of Site 534 (western North Atlantic) and of the Atlantic-Tethys seaway. In Gradstein, F. M., Sheridan, R. E., et al., Init. Repts. DSDP, 76: Washington (U.S. Govt. Printing Office), 829-884.

Patton, J. W., Choquette, P. W., Guennel, G. K., Kaltenback, A. J., and Moore, A., 1984. Organic geochemistry and sedimentology of lower to mid-Cretaceous deep-sea carbonates, Site 535 and 540 , Leg 77. In Buffler, R. T., Schlager, W., et al., Init. Repts. DSDP, 77: Washington (U.S. Govt. Printing Office), 417-443.

Pratt, L. M., 1981. A paleo-oceanographic interpretation of the sedimentary structures, clay minerals, and organic matter in a core of the Middle Cretaceous Greenhorn Formation near Pueblo, Colorado [Ph.D. dissert.]. Princeton University.

Robertson, A. H. F., and Bliefnick, D. M., 1983. Sedimentology an origin of Lower Cretaceous pelagic carbonates and redeposited clastics, Blake-Bahama Formation, Deep Sea Drilling Project Site 534, western equatorial Atlantic. In Gradstein, F. M., Sheridan, R. E., et al., Init. Repts. DSDP, 76: Washington (U.S. Govt. Printing Office), 795-828.

Roth, P. R., 1983a. Calcareous nannofossils in mid-Cretaceous black shale cycles from the Atlantic and Pacific: effects of diagenesis. Eos, 64:733-734. (Abstract)

, 1983b. Jurassic and Lower Cretaceous calcareous nannofossils in the western North Atlantic (Site 534): biostratigraphy, preservation, and some observations on biogeography and paleoceanography. In Gradstein, F. M., Sheridan, R. E., et al., Init. Repts. DSDP, 76: Washington (U.S. Govt. Printing Office), 587-621.

Scholle, P. A., and Arthur, M. A., 1980. Carbon isotope fluctuations in Cretaceous pelagic limestones: potential stratigraphic and petroleum exploration tool. Am. Assoc. Pet. Geol. Bull., 64:67-88.

Sheridan, R. E., Bates, L. G., Shipley, T. H., and Crosby, J. T., 1983. Seismic stratigraphy in the Blake-Bahama Basin and the origin of Horizon D. In Gradstein, F. M., Sheridan, R. E., et al., Init. Repts. $D S D P, 76$ : Washington (U.S. Govt. Printing Office), 667-683.

Thein, J., and von Rad, U., in press. Silica diagenesis in continental rise sediments off eastern North America (Sites 603 and 605, Leg 93; Sites 612 and 613, Leg 95). In Poag, C. W., Watts, A. B., et al., Init. Repts. DSDP, 95: Washington (U.S. Govt. Printing Office).

Tucholke, B. E., and Mountain, G. S., 1979. Seismic stratigraphy, lithostratigraphy and paleosedimentation patterns in the North American Basin. In Talwani, M., Hay, W., and Ryan, W. B. F. (Eds.), Deep Drilling Results in the Atlantic Ocean: Continental Margins and Paleoenvironment. Am. Geophys. Un., Maurice Ewing Ser. 3, 58-86.

Tucholke, B. E., and Vogt, P. R., 1979. Western North Atlantic: sedimentary evolution and aspects of tectonic history. In Tucholke, B E., Vogt, P. R., et al., Init. Repts. DSDP, 43: Washington (U.S. Govt. Printing Office), 791-825,

Vail, P. R., Mitchum, R. M., Jr., Shipley, T. H., and Buffler, R. T. 1980. Unconformities of the North Atlantic. Phil. Trans. R. Soc. London, Ser. A, 294:137-155.

Vail, P. R., and Todd, R. G., 1980. Northern North Sea Jurassic unconformities, chronostratigraphy and sea-level changes from seismic stratigraphy. In Illing, L. V., and Hobson, G. D. (Eds.), Petroleum Geology of the Continental Shelf of Northwest Europe: London (Inst. Pet.), pp. 216-235.

von Stackelberg, U., von Rad, U., and Zobel, B., 1979. Asymmetric sedimentation around Great Meteor Seamount (North Atlantic). Mar. Geol., 33:117-132.

Walker, R. G., 1967. Turbidite sedimentary structures and their relationship to proximal and distal depositional environments. J. Sed. Petrol., 37:25-43.

Weissert, H. J., McKenzie, J., and Hochuli, P., 1978. Cyclic anoxic events in the Early Cretaceous Tethys Ocean. Geology, 7:147-151.

Date of Initial Receipt: 5 August 1985

Date of Acceptance: 27 February 1986 